Prepared in cooperation with the Idaho Department of Water Resources

\title{
Seasonal Seepage Investigation on an Urbanized Reach of the Lower Boise River, Southwestern Idaho, Water Year 2010
}

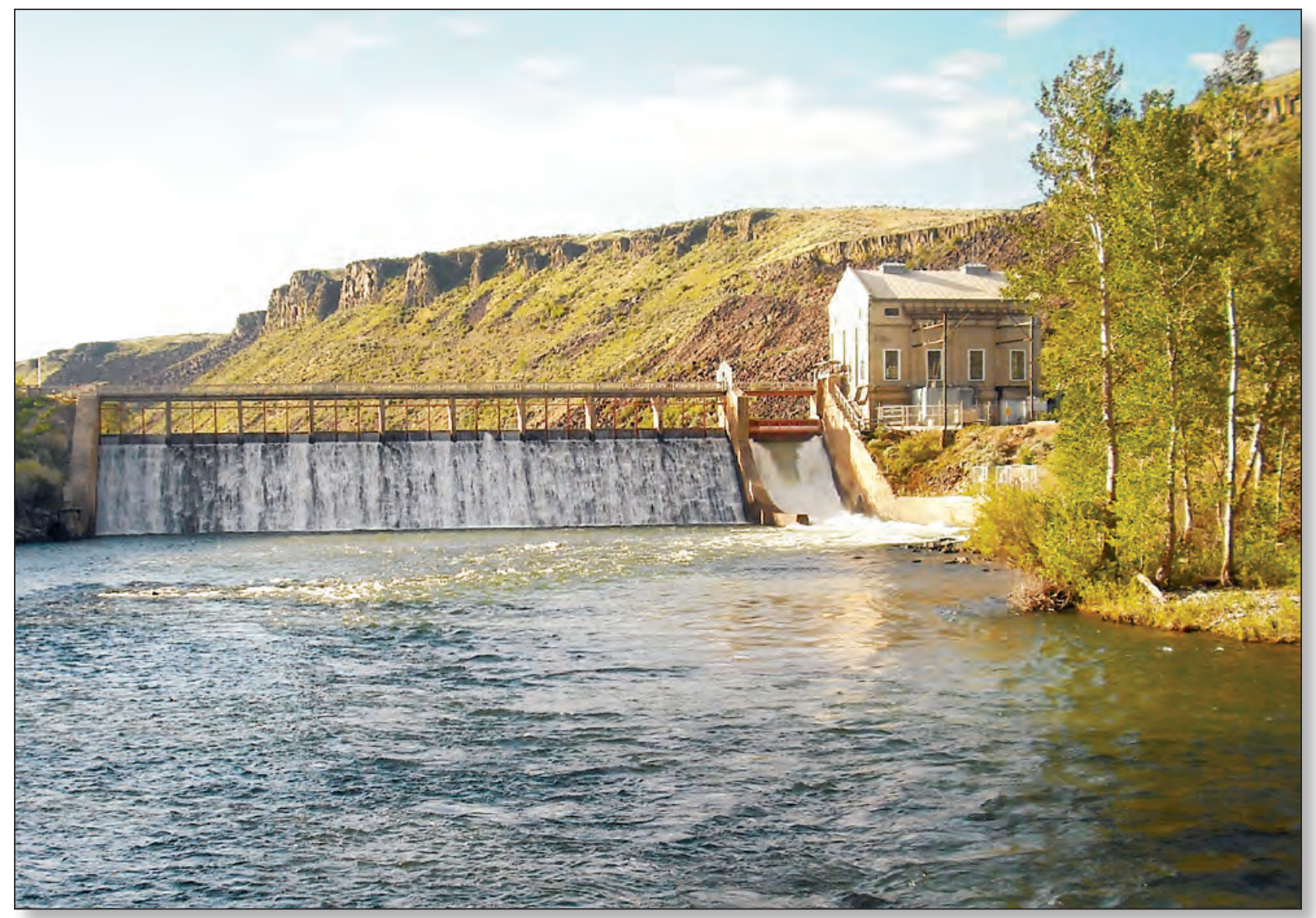

Scientific Investigations Report 2011-5181 
Cover: Photograph of the Boise River Diversion Dam, Idaho, looking upstream from inactive streamgage, Boise River below Diversion Dam (U.S. Geological Survey station No. 13203510). Photograph taken from suspended cableway by Alvin A. Sablan, U.S. Geological Survey, May 25, 2010. 


\section{Seasonal Seepage Investigation on an Urbanized Reach of the Lower Boise River, Southwestern Idaho, Water Year 2010}

By Marshall L. Williams

Prepared in cooperation with the Idaho Department of Water Resources

Scientific Investigations Report 2011-5181 


\title{
U.S. Department of the Interior \\ KEN SALAZAR, Secretary \\ U.S. Geological Survey \\ Marcia K. McNutt, Director
}

\author{
U.S. Geological Survey, Reston, Virginia: 2011
}

For more information on the USGS - the Federal source for science about the Earth, its natural and living resources, natural hazards, and the environment, visit http://www.usgs.gov or call 1-888-ASK-USGS.

For an overview of USGS information products, including maps, imagery, and publications, visit http://www.usgs.gov/pubprod

To order this and other USGS information products, visit http://store.usgs.gov

Any use of trade, product, or firm names is for descriptive purposes only and does not imply endorsement by the U.S. Government.

Although this report is in the public domain, permission must be secured from the individual copyright owners to reproduce any copyrighted materials contained within this report.

Suggested citation:

Williams, M.L., 2011, Seasonal seepage investigation on an urbanized reach of the lower Boise River, southwestern Idaho, water year 2010: U.S. Geological Survey Scientific Investigations Report 2011-5181, 24 p. 


\section{Contents}

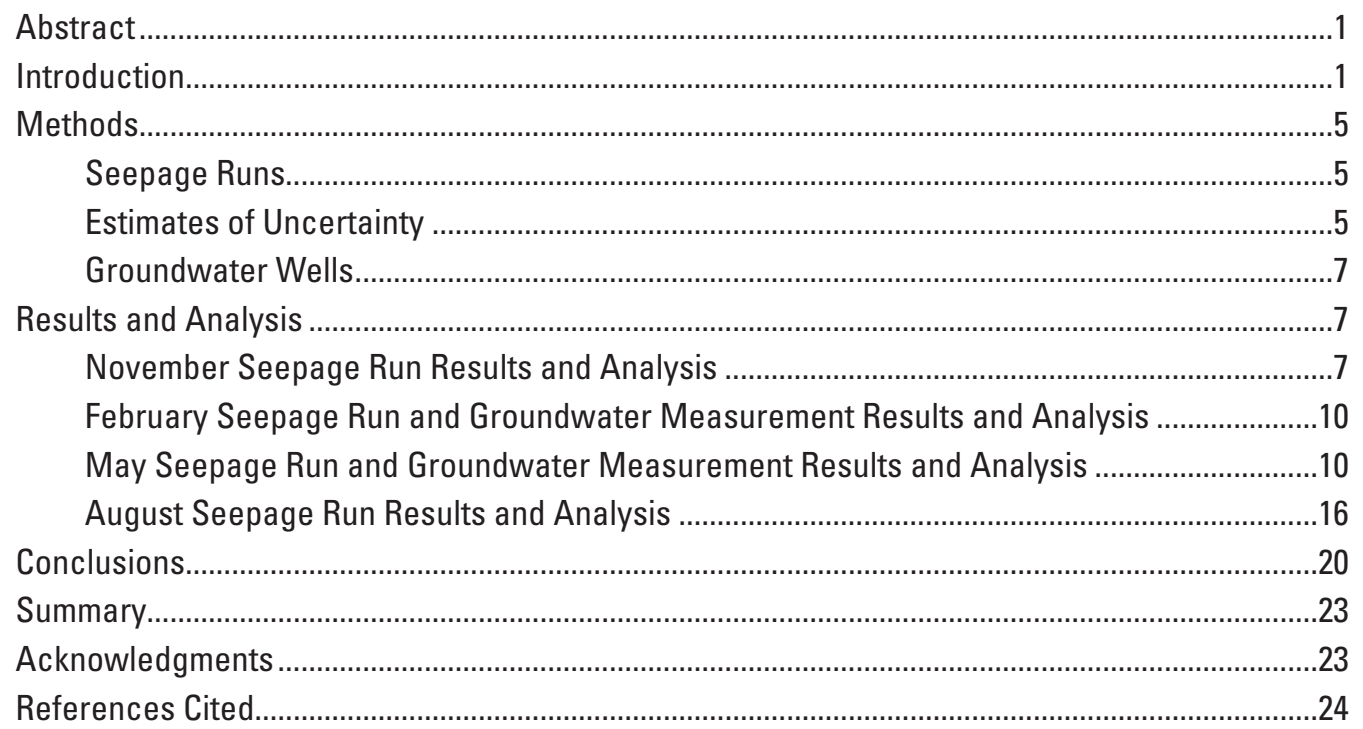

\section{Figures}

Figure 1. Map showing study reach from downstream of the Boise River Diversion Dam tothe Glenwood Bridge, Boise River, Idaho

Figure 2. Graph showing mean daily discharge, Boise River at Glenwood Bridge, Idaho, from November 1, 2009-September 1, 2010, with annotated seepage and groundwater measurements dates

Figure 3. Graph showing cumulative seasonal representative gains and losses along subreaches of the Boise River from below the Diversion Dam to the Glenwood Bridge, Boise, Idaho

Figure 4. Graph showing representative seasonal summary of the difference in hydraulic head measured at transect sites along the Boise River, Idaho 


\section{Tables}

Table 1. Seepage run and mini-piezometer measurement site locations, and descriptions on selected reaches of the Boise River, Idaho

Table 2. Summary of instruments used to conduct discharge measurements and the measurements' associated uncertainty statistic by date and location on the Boise River, Idaho

Table 3. Summary of discharge measurements, calculated gain and loss estimates, and associated estimates of uncertainty on selected reaches of the Boise River, Idaho, November 5, 2009

Table 4. Summary of discharge measurements, calculated gain and loss estimates, and associated estimates of uncertainty on selected reaches of the Boise River, Idaho, February 8, 2010

Table 5. Summary of left and right bank, surface water and groundwater hydraulic head measurements, and their difference, at selected locations along the Boise River, Idaho, February 8, 2010. .

Table 6. Summary of discharge measurements, calculated gain and loss estimates, and associated estimates of uncertainty on selected reaches of the Boise River, Idaho, May 25, 2010

Table 7. Summary of left and right bank, surface water and groundwater hydraulic head measurements, and their difference, at selected locations along the Boise River, Idaho, May 25, 2010

Table 8. Summary of discharge measurements, calculated gain and loss estimates, and associated estimates of uncertainty on selected reaches of the Boise River, Idaho, August 3, 2010

Table 9. Seasonal summary of mainstem discharge measurements, with calculated gain and loss estimates, and associated estimates of uncertainty, during water year 2010 , on selected reaches of the Boise River, Idaho

\section{Conversion Factors and Datum}

Conversion Factors

\begin{tabular}{lll}
\hline \multicolumn{1}{c}{ Multiply } & By & \multicolumn{1}{c}{ To obtain } \\
\hline inch (in) & Length & \\
foot (ft) & 2.54 & centimeter $(\mathrm{cm})$ \\
mile (mi) & 0.3048 & meter $(\mathrm{m})$ \\
& 1.609 & kilometer $(\mathrm{km})$ \\
\hline cubic foot per second $\left(\mathrm{ft}^{3} / \mathrm{s}\right)$ & Flow rate & \\
cubic foot per second per square & 0.02832 & cubic meter per second $\left(\mathrm{m}^{3} / \mathrm{s}\right)$ \\
mile $\left[\left(\mathrm{ft}^{3} / \mathrm{s}\right) / \mathrm{mi}^{2}\right]$ & 0.0176 & cubic meter per second per \\
\hline
\end{tabular}

Datum

Horizontal coordinate information is referenced to World Geodetic System of 1984 (WGS 84). 


\title{
Seasonal Seepage Investigation on an Urbanized Reach of the Lower Boise River, Southwestern Idaho, Water Year 2010
}

\author{
By Marshall L. Williams
}

\section{Abstract}

The U.S. Geological Survey in cooperation with the Idaho Department of Water Resources Treasure Valley Comprehensive Aquifer Management Planning effort investigated seasonal groundwater gains and losses on the Boise River, Idaho, starting in November 2009 through August 2010. The investigation was conducted using seepage runs in 11 subreaches over a 14-mile reach from downstream of the inactive streamgage, Boise River below Diversion Dam (U.S. Geological Survey station No. 13203510) to the active Boise River at Glenwood Bridge streamgage (U.S. Geological Survey station No. 13206000). The seepage runs measured mainstem discharge, and significant tributary contributions and diversions along the reach. In addition, an evaluation of the groundwater hydraulic gradient was simultaneously conducted through shallow groundwater mini-piezometers adjacent to the river during February (low stream discharge) and May (high stream discharge) measurement timeframes.

November discharge estimates, representative of autumn, had gains and losses that varied by subreach with an overall net gain of $42 \pm 8$ cubic feet per second $\left(\mathrm{ft}^{3} / \mathrm{s}\right)$. This finding compares favorably to a previous U.S. Geological Survey seepage investigation in November 1996 that found a gaining reach with an estimated gain of $52 \mathrm{ft}^{3} / \mathrm{s}$. This finding also is supported by a U.S. Geological Survey investigation in the study reach in November 1971 that estimated a gain of $74 \mathrm{ft} 3 / \mathrm{s}$, which largely came from groundwater. The February discharge estimates, representative of winter conditions, showed variability in the reach with a net gain of $52 \mathrm{ft}^{3} / \mathrm{s}$ with an uncertainty estimate of $\pm 7 \mathrm{ft}^{3} / \mathrm{s}$, which is consistent with the low stream discharge findings from November 2009. This finding is further supported by the differential hydraulic head measured at transect sites that qualitatively indicated groundwater to surface-water movement with few exceptions. The May discharge estimates, representative of the springtime conditions, were gaining or potentially gaining in all but one of the upper subreaches between Boise River below Diversion Dam and Boise River near MK Nature Center sites, with seepage run results supported by hydraulic head differentials indicating a groundwater to surface-water movement. The lower end of the study reach between Boise River near MK Nature Center and Boise River at Glenwood Bridge sites showed more variability with observed hydraulic head differentials that partially supported the potential gains or losses in the reach. Overall, the reach had a calculated net gain of $24 \pm 51 \mathrm{ft}^{3} / \mathrm{s}$ and, therefore, this estimate may or may not reflect the actual conditions in the reach. The groundwater gains and losses in August, representative of summer conditions, varied in both the upper and lower parts of the reach, with a net loss of $-88 \pm 69 \mathrm{ft}^{3} / \mathrm{s}$.

Overall, the reach experienced a net gain from groundwater at low stream discharges (November and February), a net loss to groundwater at moderately high stream discharge (August), and an ambiguous finding at a higher stream discharge (May). The hydraulic head differentials measured between the groundwater and surface water largely supported the calculated gain and loss estimates in the subreaches, with a potential for groundwater to surface-water movement at low stream discharge in February, and variability during high stream discharge conditions in May.

\section{Introduction}

The Boise, Idaho metropolitan area has experienced rapid population growth for more than two decades with associated land use changes from traditional agricultural practices to urbanized commercial, residential, and manufacturing environments. Concern for future water resources has spurred research into evaluating the status of current water resources in order to create strategies to meet future needs. The U.S. Geological Survey (USGS) in cooperation with the Idaho Department of Water Resources (IDWR) Treasure Valley Comprehensive Aquifer Management Planning (CAMP) effort investigated seasonal groundwater gains and losses on the Boise River, Idaho (fig. 1), from November 2009 through August 2010. The investigation was conducted using seepage runs and evaluation of the groundwater hydraulic gradient observed at shallow groundwater wells (mini-piezometers) adjacent to the river. 


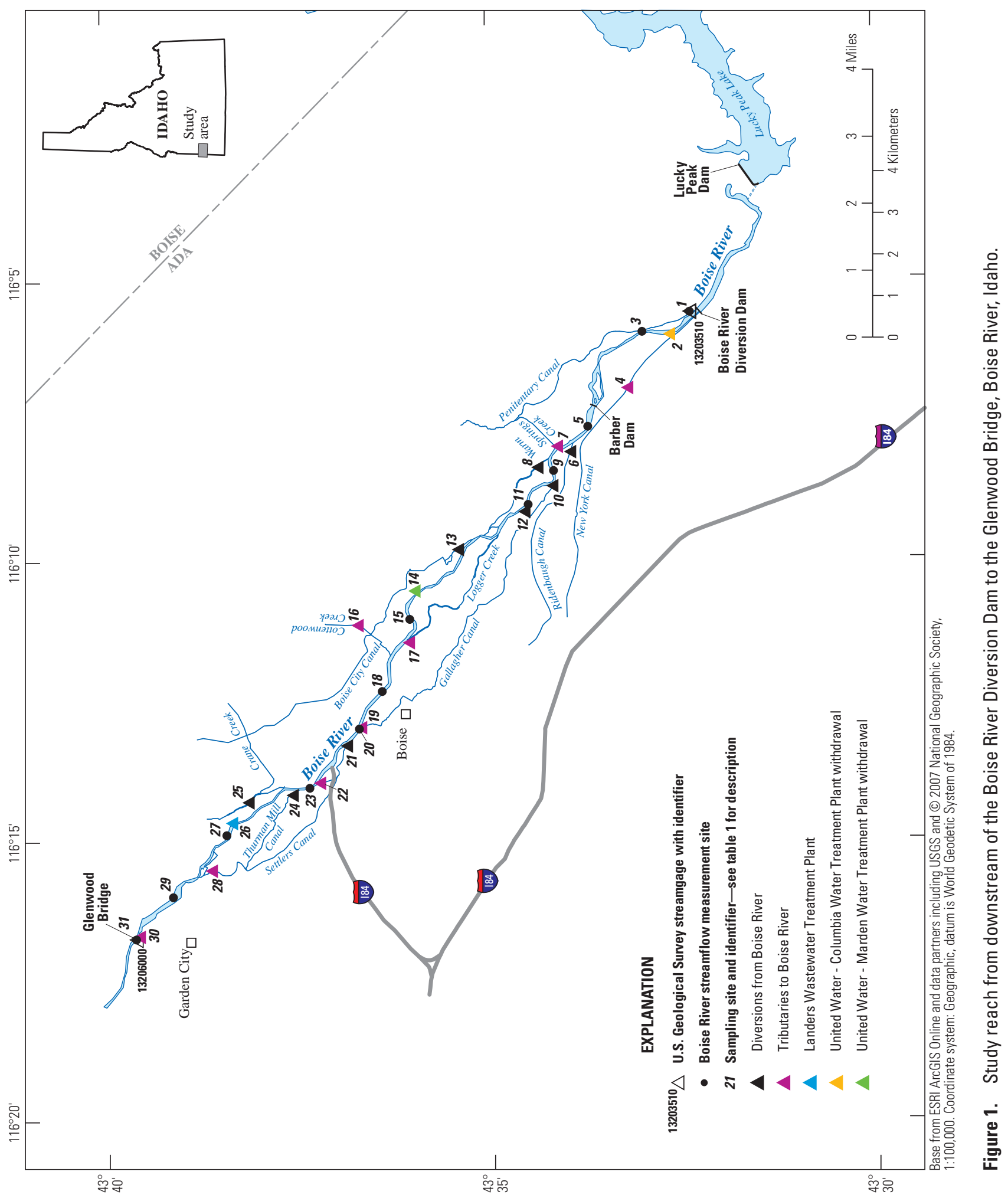


Geographically, the lower Boise River begins at the base of the mountains near Lucky Peak Reservoir with stream discharge in the study reach controlled by water releases from Lucky Peak Dam (fig. 1), which is located 2.33 mi upstream of the first measurement site. During the irrigation season (approximately early-April to mid-October), the Boise River Diversion Dam upstream of the first measurement site, also controls a measure of stream discharge as it diverts water from the Boise River to the New York canal network to meet agricultural irrigation needs in the valley. The studied reach includes multiple smaller diversions (irrigation and municipal) and natural tributary inflows. The river flows through the city of Boise, and is bounded on the north by foothills and mountains, and to the south by low rolling hills with relatively flat topography.

The studied reach runs from an inactive streamgage, Boise River below Diversion Dam (USGS station No. 13203510) and ends at the active streamgage, Boise River at Glenwood Bridge (USGS station No. 13206000), a distance of nearly 14 river miles. Data from this seepage investigation supports IDWR's Treasure Valley CAMP goals of providing reliable sources of water into the future, and bridging gaps between future water needs and supplies.

Seepage runs are a series of stream discharge measurements that are conducted to understand spatial variation in stream discharge gain and loss that can be attributed to groundwater in a specified reach (Rosenberry and LaBaugh, 2008). A seepage study conducted in November 1996 by the USGS found a net gain from groundwater in the reach downstream of Lucky Peak Dam to the Glenwood Bridge (Berenbrock, 1999). In discussions with IDWR, it was agreed that the 1996 data should be enhanced by examining the temporal and spatial gains and losses during the ambient conditions typical of the four seasons. The seepage runs were timed to coincide with stable flow conditions and conducted as close to mid-season as possible (fig. 2):

- Autumn-low stream discharge after the end of irrigation season (November)

- Winter-low stream discharge outside of irrigation season (February)

- Spring — high stream discharge after the beginning of irrigation season (May)

- Summer-mid to high stream discharge after midirrigation season (August)

The studied reach was divided into 11 subreaches between 12 mainstem measurement sites (table 1). Anomalous stream discharge losses at site 3 (Boise River below Highway 21) lead to the discovery of a side-channel diversion that skirted the measurement site during high

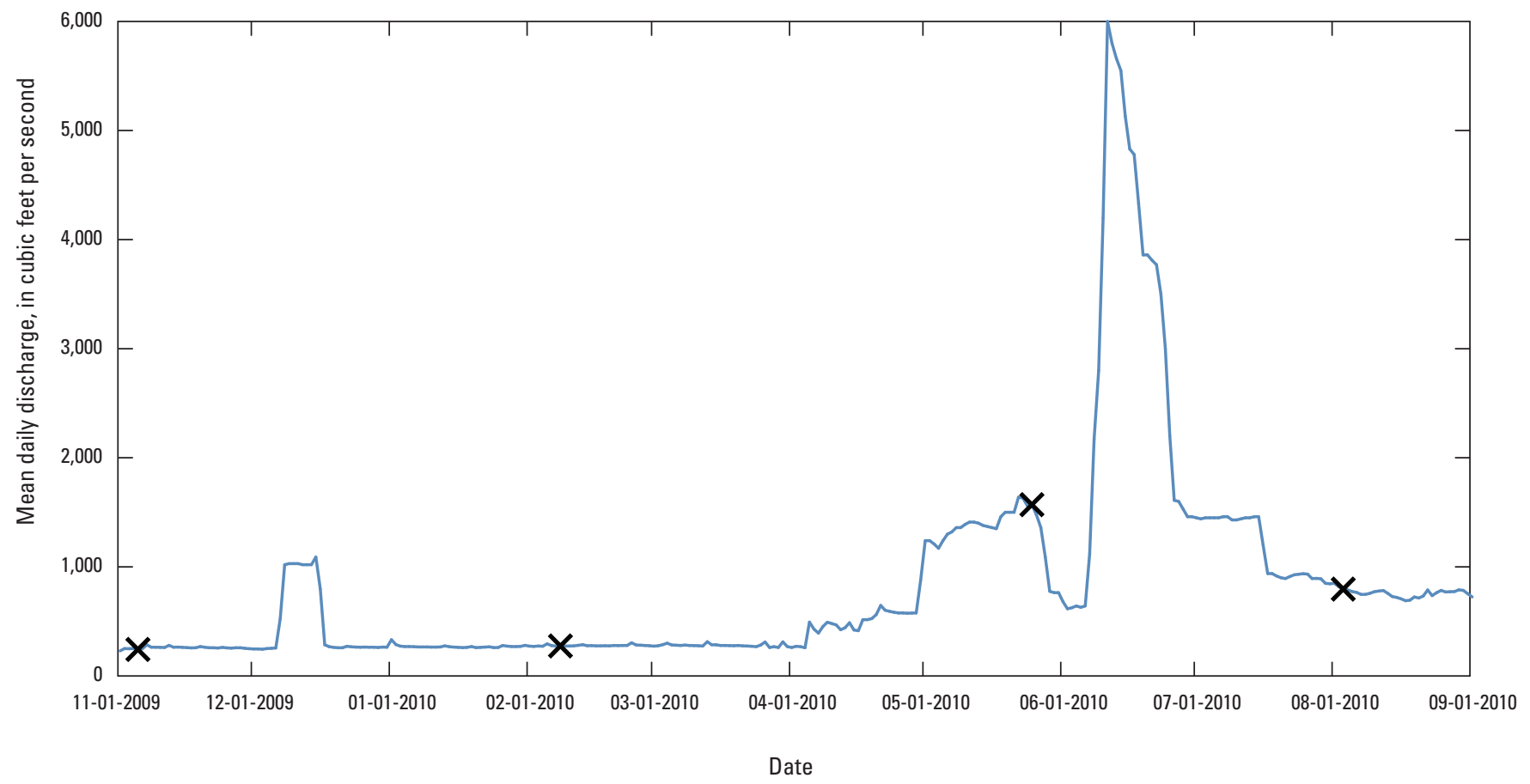

Figure 2. Mean daily discharge, Boise River at Glenwood Bridge (USGS 13206000), Idaho, from November 1, 2009September 1, 2010, with annotated seepage and groundwater measurements dates. 


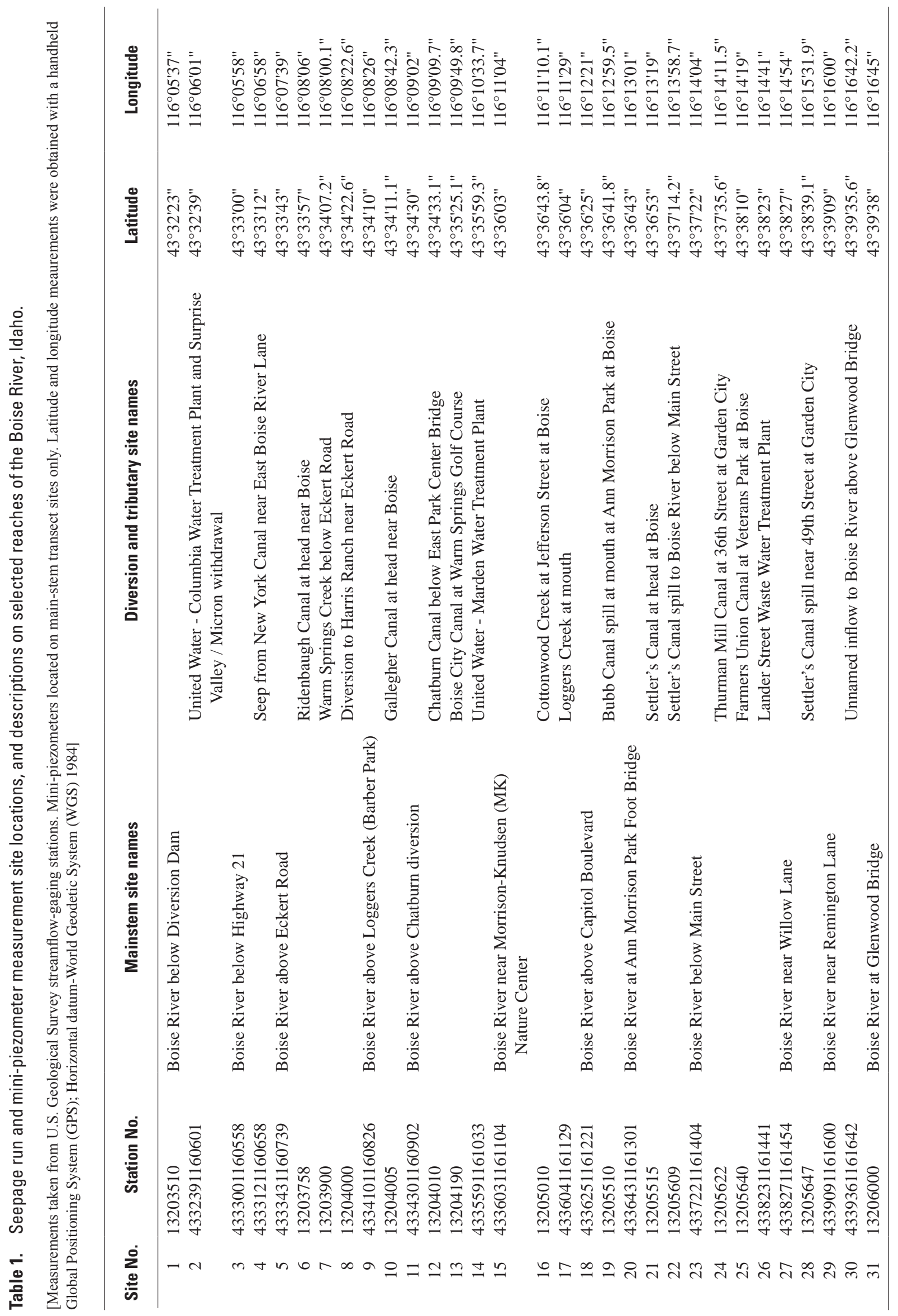


stream discharge. The side channel was dry during low stream discharge, and was not readily apparent during initial site selection. To eliminate the influence of unmeasured discharge at this site, gains and losses were calculated between sites 1 and 5 , thus eliminating the discharge bypass during high stream discharges. Left and right bank mini-piezometers remained installed at the original site 3 transect. All measurement sites were selected based on USGS suitability criteria for discharge measurements (Rantz and others, 1982; Mueller and Wagner, 2009). Along the studied reach, 9 tributaries (inflows) and 10 diversions (outflows) were quantified to determine significant contributions or withdrawals to the Boise River. In situations where water treatment facilities discharge to, or withdraw from, the Boise River, the values were provided by the utility for the days stream discharge measurements were conducted. To provide ancillary data to the seepage run gain and loss estimates, measurements of hydraulic head differences between the groundwater (mini-piezometers) and the surface water at low (February) and high (May) stream discharges also were conducted to provide a qualitative assessment of potential groundwater and surface water interaction on both the left and right banks at the mainstem transect sites.

\section{Methods}

Stream discharge measurements were conducted in accordance with USGS Office of Surface Water protocols, policies, and published guidance (Rantz and others, 1982; Oberg, and others, 2005; Mueller and Wagner, 2009). The instruments used to conduct the measurements were either YSI SonTek FlowTracker handheld acoustic Doppler velocimeters (ADV) or Teledyne RDI StreamPro acoustic Doppler current profilers (ADCP) and were selected based on ambient stream discharge conditions. Hydraulic head differential measurements were conducted in accordance with USGS guidance found in $F$ ield Techniques for Estimating Water Fluxes Between Surface Water and G round Water (Rosenberry and LaBaugh, 2008). Geographic coordinates provided for the measurement sites were based on a hand-held Global Positioning System, using the World Geodetic System 1984 horizontal datum.

\section{Seepage Runs}

The seepage runs were conducted during a single day; stable flows were requested from the Boise River watermaster through IDWR for each sampling date. Dates selected for sampling within the seasonal timeframes were: November 5 , 2009 (autumn); February 8, 2010 (winter); May 25, 2010 (spring); and August 3, 2010 (summer). During the seepage runs, discharge measurements were made at sites along the mainstem of the river, and significant inflows and outflows were measured along the subreaches. The increase or decrease between mainstem measurement sites that could not be attributed to inflows or outflows represents the net seepage interchange between the surface water and the groundwater. The mass balance equation used for determining this estimate is as follows (Simonds and Sinclair, 2002):

$$
\text { Net seepage gain or loss }=0 d-T-O u+D \text {, }
$$

where

$\mathrm{Od}$ is the discharge measured at the downstream end of the reach, in cubic feet per second;

$\mathrm{Ou}$ is the discharge measured at the upstream end of the reach, in cubic feet per second;

$T$ is the sum of tributary inflows, in cubic feet per second; and

D is the sum of the diversion outflows, in cubic feet per second.

The result is the estimated net volume of water gained or lost from the river. Positive values indicate a gaining reach, and negative values show a loss of water volume.

\section{Estimates of Uncertainty}

The estimates of uncertainty for the stream discharge measurements were calculated differently depending on the instrument used to conduct the discharge measurement. The FlowTracker ADV calculates uncertainty internally through a statistical technique developed by the USGS, and outputs a statistical uncertainty value in percent at the completion of the measurement. This value was used to estimate uncertainty for the discharge measurements. For a full discussion on methodology, see F lowTracker H andheld ADV Technical M anual, from SonTek (SonTek/YSI, 2009).

The uncertainty in the ADCP measurements was determined by first finding the t-statistic for a normal distribution at the 95-percent confidence interval based on the number of transects measured (degrees of freedom, $n-1$ ). To calculate a margin of error for the confidence interval, this value is multiplied by the coefficient of variation (CV) divided by the square root of the sample number, $n$, and multiplied by 100 to provide an uncertainty value in percent, for the variance around the mean discharge estimate. This value is random uncertainty; bias in the measurements between sites is considered negligible due to the same instrument being used to conduct the mainstem measurements in all but one instance. Table 2 provides a summary of the instruments used to conduct discharge measurements and measurement associated uncertainty statistics. 


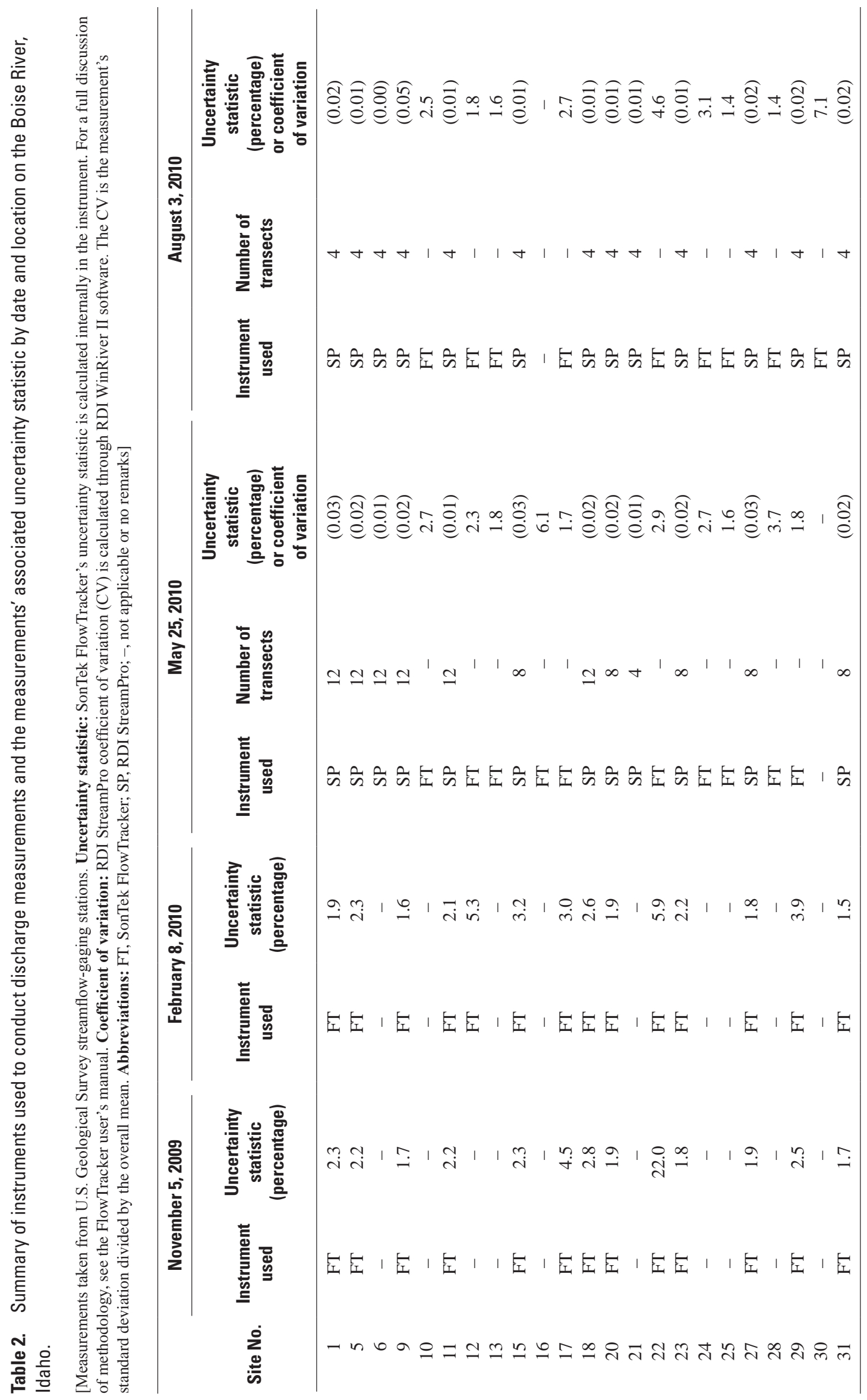


As an example, a value for the t-statistic appropriate for four transects, with $\alpha=0.025$ (two-tailed probability), is 3.182. This factor is multiplied by the measurement CV, in this case 0.03 , divided by the square root of the number of transects, then multiply by 100 . The result is a 95 percent confidence interval on a 4.8 percent variance around the mean discharge.

- Uncertainty, in percent $=\left(t_{a}, n-1 * C V / \sqrt{ } n\right) * 100$

- Uncertainty, in percent $=(3.182 * 0.03 / \sqrt{ } 4) * 100$

$$
= \pm 4.8 \text { percent }
$$

Once uncertainty is determined for each measurement, the propagation of uncertainty was estimated to determine if the net gain or loss estimate exceeds the propagated error. To estimate uncertainty for the groundwater gain or loss within a subreach, apply the following formula (Wheeler and Eddy-Miller, 2005):

$$
s=\sqrt{( \pm a)^{2}+( \pm b)^{2} \ldots+( \pm n)^{2}},
$$

where

$S$ is the uncertainty for all measurement estimates in the subreach; and $a, b, \ldots, n$ are the mean estimates of uncertainty for each individual discharge measurement.

As an example, the stream discharge estimates on August 3, 2010, for sites 9 to 11 in table 8, have calculated uncertainty values for each measurement used in the following equation:

$$
\begin{aligned}
S & =\sqrt{( \pm 82.4)^{2}+( \pm 0.119)^{2}+( \pm 18.1)^{2}} \\
& = \pm 84.4 \text { cubic feet per second. }
\end{aligned}
$$

The net groundwater gain or loss would have to be greater than $\pm 84.4 \mathrm{ft}^{3} / \mathrm{s}$ to determine the groundwater component in the reach. Because the calculated net gain was $105 \mathrm{ft}^{3} / \mathrm{s}$, and is greater than the uncertainty estimate, the net gain likely represents actual conditions at the time of the measurement.

\section{Groundwater Wells}

Qualitatively, the direction of movement between the river and shallow groundwater was determined by the hydraulic head differential between them. This was accomplished using mini-piezometers installed on both the left and right banks at the mainstem transect sites and using a manometer board to measure the difference in hydraulic head between the river and the shallow groundwater. For the purposes of this report, positive hydraulic head differential values indicate a potential for groundwater-to-surface water movement; negative values indicate a potential for surface water-to-groundwater movement. A detailed description of manometer board usage is presented in Winter and others (1988).

The mini-piezometers were constructed of $1 / 2$-inch galvanized metal pipe with one end of the pipe crimped shut to provide a drive point and 1/8-inch holes drilled around the lower 6 in. of pipe to allow water access, and act as a filter for sediment. Each well was driven to a depth of approximately $7 \mathrm{ft}$, or to a point where further progress was stopped: a depth range of 3-7 ft.

\section{Results and Analysis}

\section{November Seepage Run Results and Analysis}

Stream discharge measurements were conducted on November 5, 2009, along the Boise River, from downstream of the Boise River Diversion Dam to the Glenwood Bridge, with significant returns, tributaries, diversions, and withdrawals measured along the reach. A discharge of $218 \mathrm{ft}^{3} / \mathrm{s}$ was measured at site 1 , downstream of the Boise River Diversion Dam (fig. 1) at approximately 9:00 a.m. Mountain Standard Time (MST). Irrigation season had ended approximately the second week of October and the National Weather Service (NWS) (2008) reported no measureable precipitation at the Boise Airport within 5 days preceding the measurements. All outflows were zero, with the exception of withdrawals by the United Water (UW) Marden Water Treatment Plant (WTP), the UW Columbia WTP and Surprise Valley/Micron combined withdrawal, and the Chatburn diversion (open year round). Several inflows had measureable discharge and Landers Street Waste Water Treatment Plant (WWTP) was contributing to the river.

All subreaches had gains or losses greater than the estimates of uncertainty with the exceptions of subreaches $5-9,15-18$, and 29-31. The greatest net gain was between sites 11 and 15 with $32 \pm 8 \mathrm{ft} 3 / \mathrm{s}$, and the greatest net loss was between sites 23 and 27 with $-18.0 \pm 6.09 \mathrm{ft}^{3} / \mathrm{s}$. Overall, there was a net gain in the reach of $42 \pm 8 \mathrm{ft}^{3} / \mathrm{s}$ (table 3 ). This finding reflects the results of the November 1996 USGS seepage study (Berenbrock, 1999) which found this reach to have a calculated net gain of $52 \mathrm{ft}^{3} / \mathrm{s}$. This also is consistent with an earlier USGS investigation on the Boise River conducted by Thomas and Dion (1974) that found groundwater made up nearly all stream discharge on the Boise River below Lucky Peak Dam, when discharge gates on the dam were completely closed from November 17 to 20, 1971. The USGS used the opportunity to measure discharge from gage equipment on the dam gates, Boise River near Boise (USGS station No.13202000, currently inactive), to the Glenwood Bridge (formerly known as Strawberry Glenn Bridge) from November 18 to 19, 1971. Stream discharge at the dam gates measured $0.99 \mathrm{ft}^{3} / \mathrm{s}$ and increased along the study reach to a stream discharge of $74.8 \mathrm{ft}^{3} / \mathrm{s}$ at the Glenwood Bridge. (See Thomas and Dion, 1974, for additional details.) 


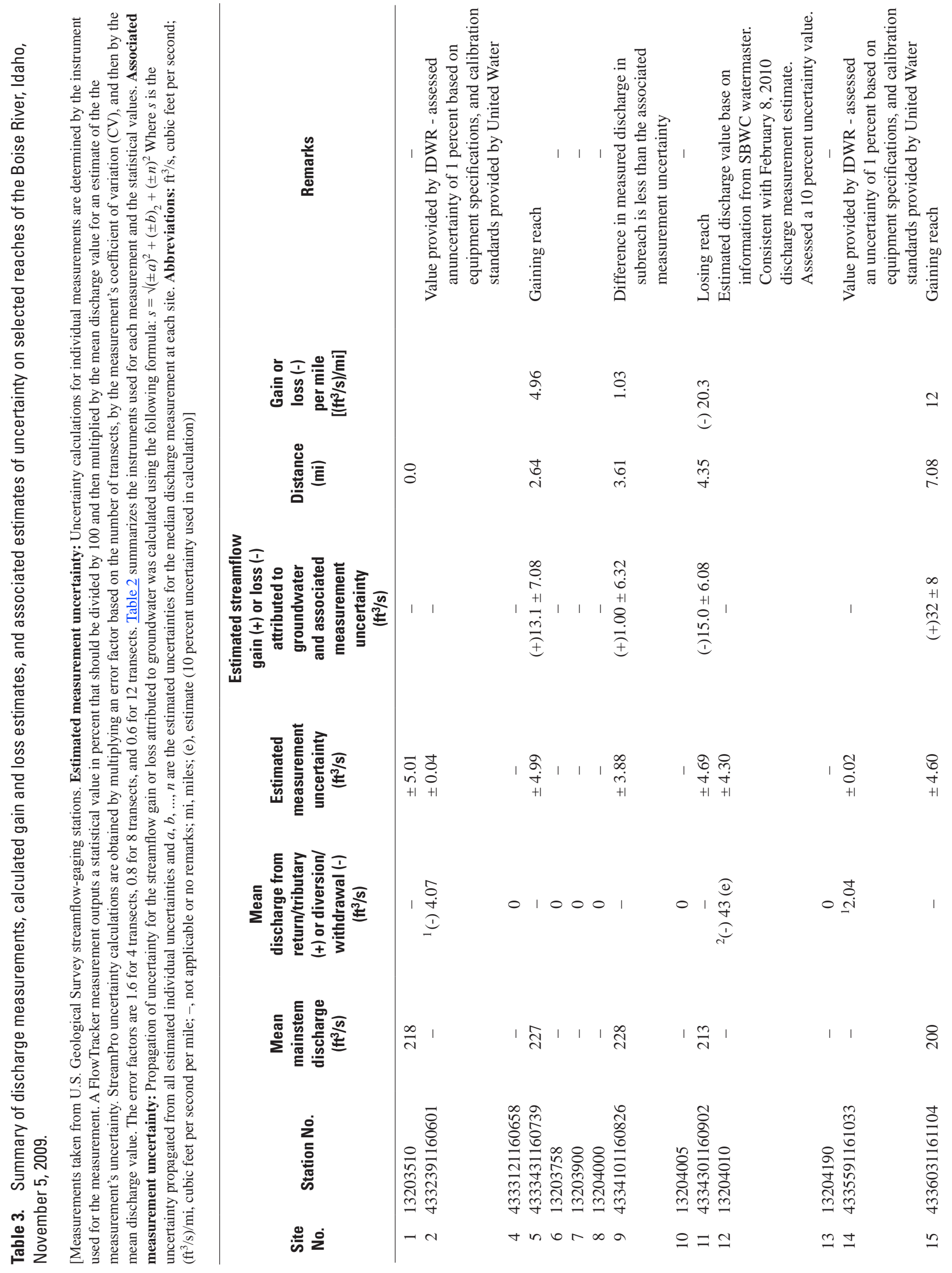



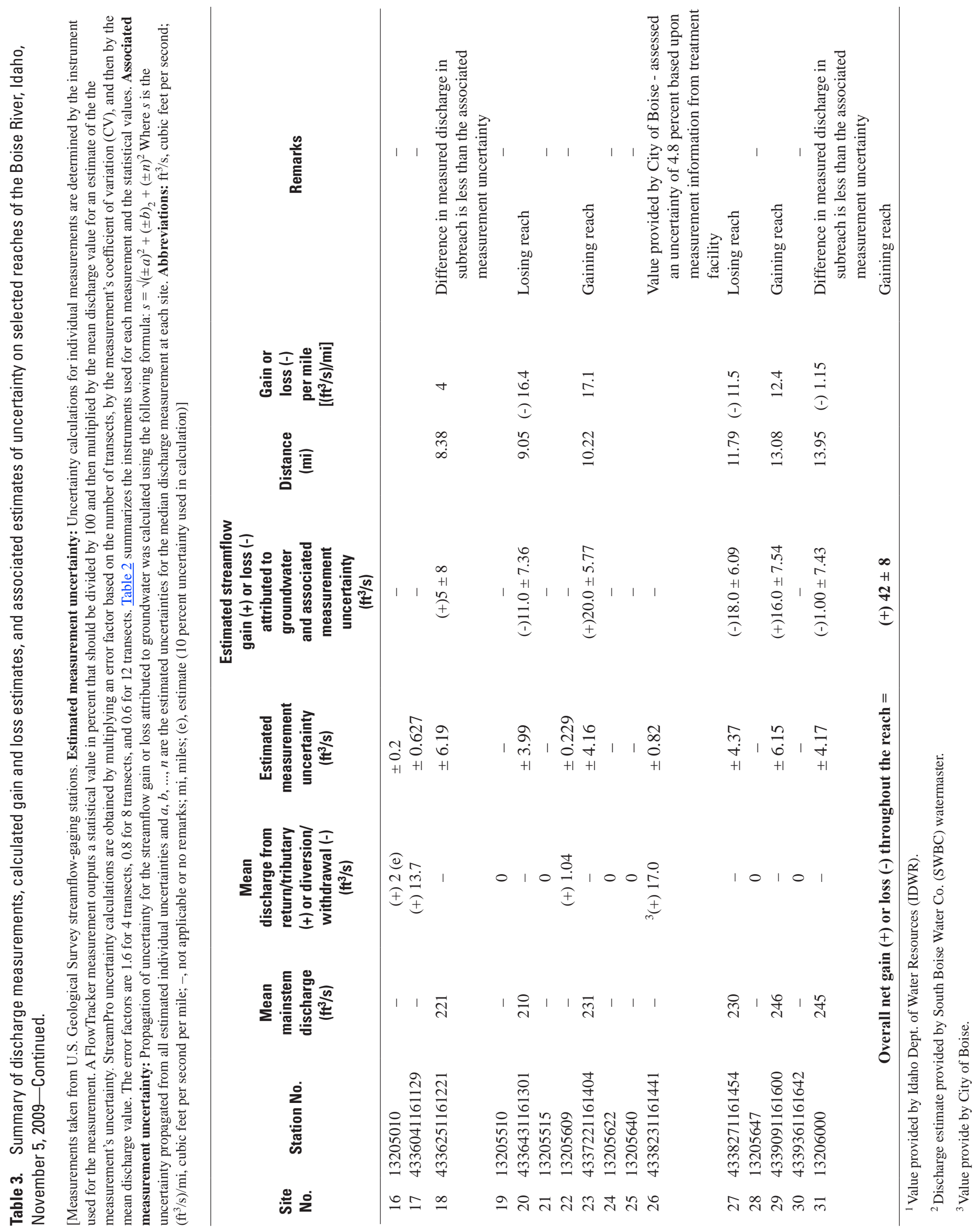


\section{February Seepage Run and Groundwater Measurement Results and Analysis}

Stream discharge measurements were conducted on February 8, 2010, along the Boise River, from downstream of the Boise River Diversion Dam to the Glenwood Bridge, with significant returns, tributaries, diversions, and withdrawals measured along the reach. A discharge of $240 \mathrm{ft}^{3} / \mathrm{s}$ was measured at site 1 , downstream of the Diversion Dam at approximately 9:00 a.m. MST. No irrigation flows were present and the National Weather Service (2008) reported 0.27 in. of measureable precipitation at the Boise Airport within 5 days preceding the measurements. All outflows were zero, with the exception of withdrawals by the UW Marden WTP, the UW Columbia WTP and Surprise Valley/Micron combined withdrawal, and the Chatburn diversion (open year round). Several inflows had measureable discharge and Landers Street WWTP was contributing to the river.

All subreaches had gains or losses greater than the estimates of uncertainty with the exceptions of subreaches 15-18, 18-20, and 27-29. The greatest net gain was between sites 11 and 15 with $30.2 \pm 8.95 \mathrm{ft}^{3} / \mathrm{s}$, and the greatest net loss was between sites 23 and 27 with $-20.0 \pm 7.49 \mathrm{ft}^{3} / \mathrm{s}$. Overall, there was a net gain in the reach of $52 \pm 7 \mathrm{ft}^{3} / \mathrm{s}$ (table 4), which is consistent with the low stream discharge findings in November 2009, and USGS studies conducted in November 1996 (Berenbrock, 1999) and November 1971 (Thomas and Dion, 1974).

Differential hydraulic head measurements were conducted at mini-piezometers installed along the main reach. The results indicate that there is a potential for groundwater to surface-water movement throughout the reach, with some exceptions (table 5). Specifically, there is the potential for groundwater to surface-water movement on the right bank at sites 9 and 15, and the following four sites were found dry: right bank at site 23, and left bank at sites, 5, 15, and 23.

The majority of hydraulic head differentials indicate a potential groundwater to surface-water movement with the left bank at site 1 having the largest positive hydraulic head differential of $0.38 \mathrm{ft}$. The results qualitatively support the seepage run findings with one notable exception. The hydraulic head differential at site 15 had the largest negative differential of all well measurements at $-0.47 \mathrm{ft}$ and indicated the greatest potential for groundwater to surface-water movement in the reach. United Water operates a Ranney collector approximately $0.4 \mathrm{mi}$ upstream of the observation well, between sites 11 and 15, but there was no withdrawal on the day the measurement was conducted and it is unlikely the collector was a significant factor with regard to groundwater movement on February 8, 2010.

\section{May Seepage Run and Groundwater Measurement Results and Analysis}

Stream discharge measurements were conducted on May 25, 2010, along the Boise River, from downstream of the Boise River Diversion Dam to the Glenwood Bridge, with significant returns, tributaries, diversions, and withdrawals measured along the reach. A discharge of 2,410 ft $3 / \mathrm{s}$ was measured at site 1 , downstream of the Diversion Dam at approximately 8:30 a.m. MST. Irrigation season had started approximately the first week of April, and the National Weather Service (2008) reported 1.42 in. of measureable precipitation at the Boise Airport within 5 days preceding the measurements. The irrigation season, and spring rains, produced significant tributary contribution and diversions along the reach.

Only subreaches 1-5, 9-11, and 11-15 had calculated gains or losses that exceeded the estimates of uncertainty. The greatest gain in the reach was between sites 11 and 15 with $80.0 \pm 46.8 \mathrm{ft}^{3} / \mathrm{s}$, and the greatest loss was between sites 1 and 5 with $-72 \pm 52 \mathrm{ft}^{3} / \mathrm{s}$. Overall, there was a calculated net gain of $24 \pm 51 \mathrm{ft}^{3} / \mathrm{s}$ (table 6 ). Because the net gain was less than the estimate of uncertainty, the gain may or may not reflect real conditions in the reach. However, individual gains and losses in the subreaches, when compared to the differential hydraulic head measurements, provide a qualitative assessment of groundwater movement at the mainstem transect sites. In many cases (13 of 22 measurements), the direction for potential groundwater movement agreed with the findings of the seepage runs and qualitatively supported the results within the subreaches, but in some cases it did not. Hyporheic flow often varies along a reach due to the heterogeneity of fluvial sediments (Rosenberry and LaBaugh, 2008), which may explain why some hydraulic head differentials did not agree with seepage run results. In addition, hydraulic head differential measurements are single points along the reach and are representative of groundwater interchange at that particular point, not along an entire subreach. 

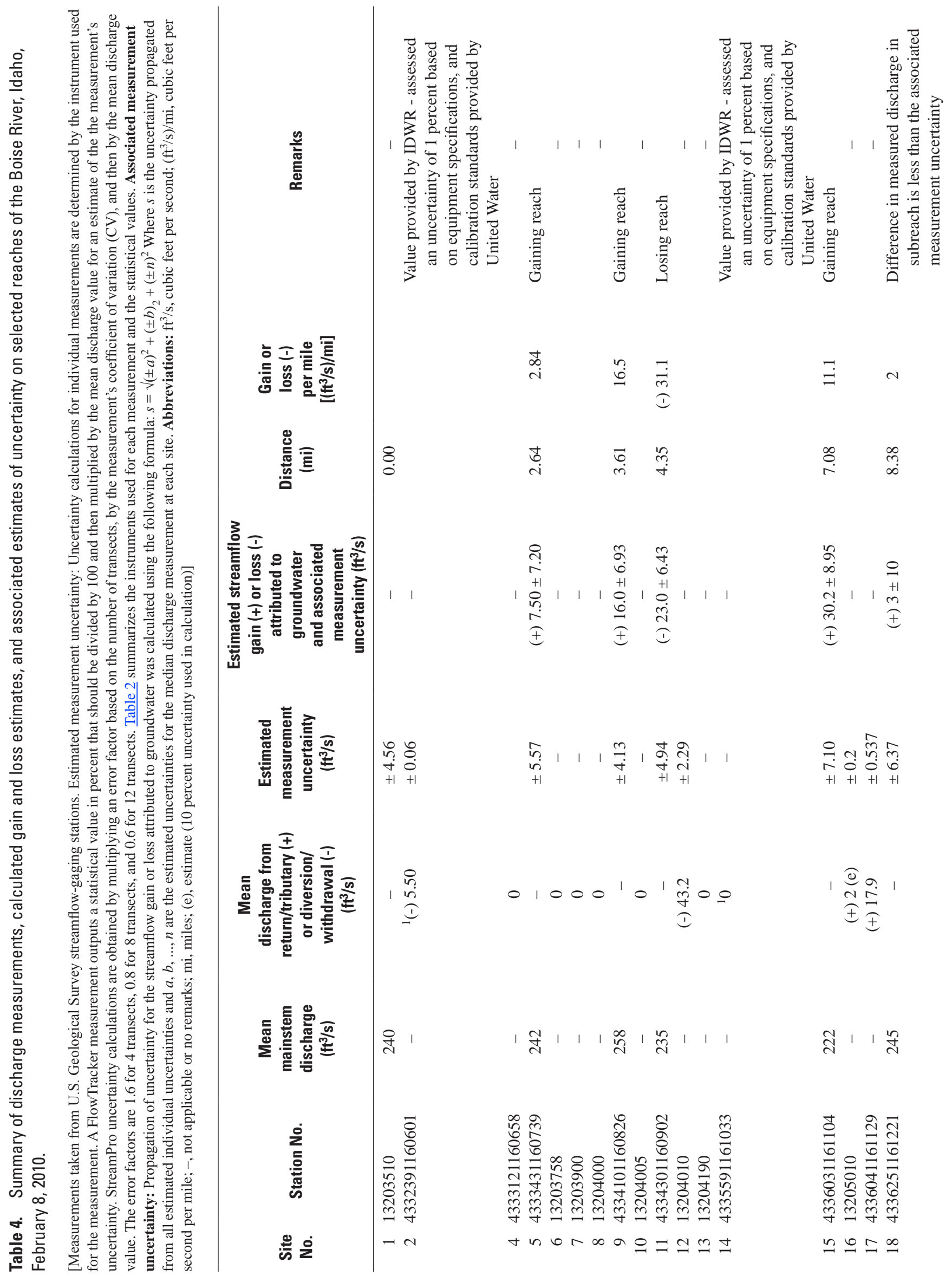


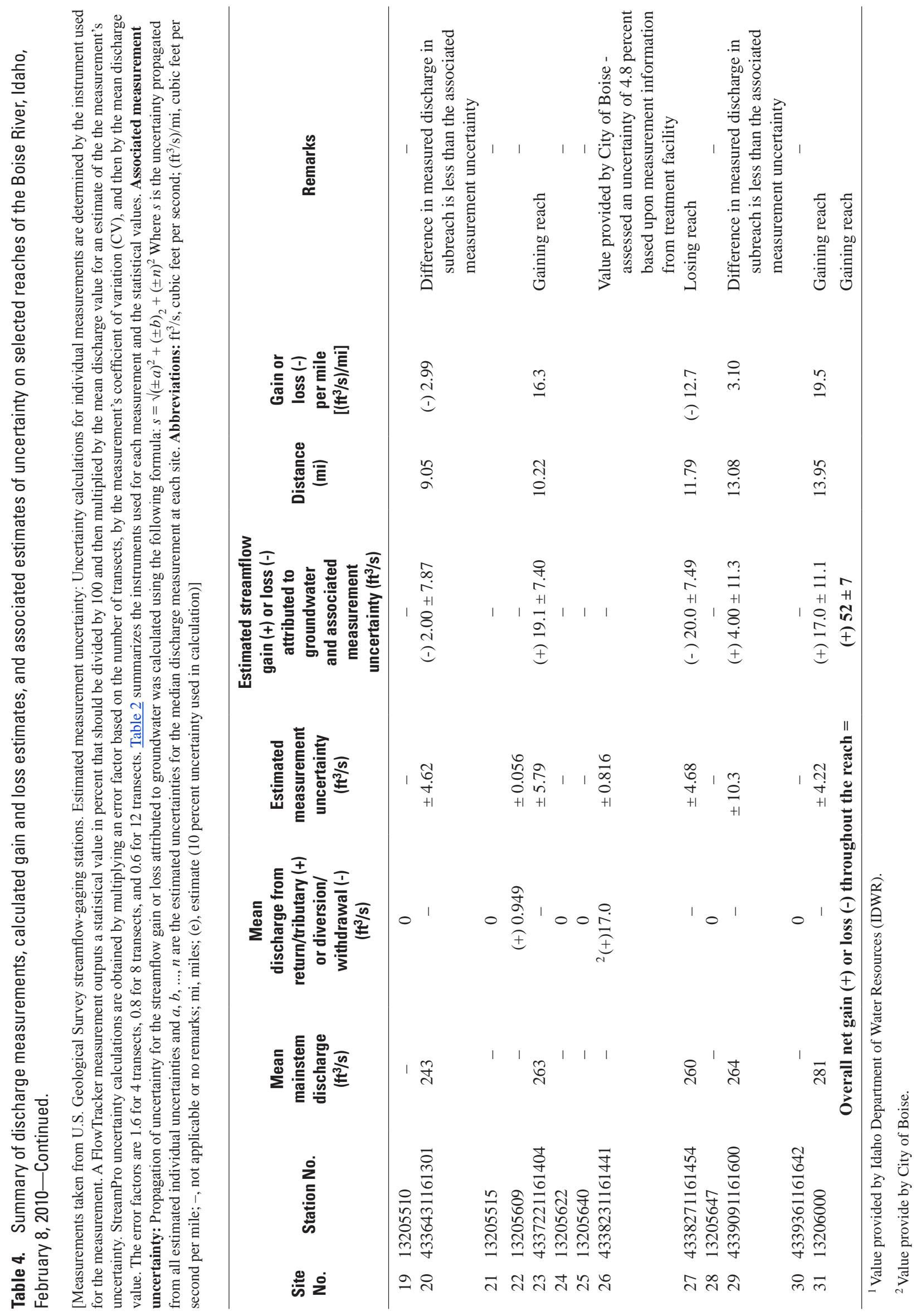




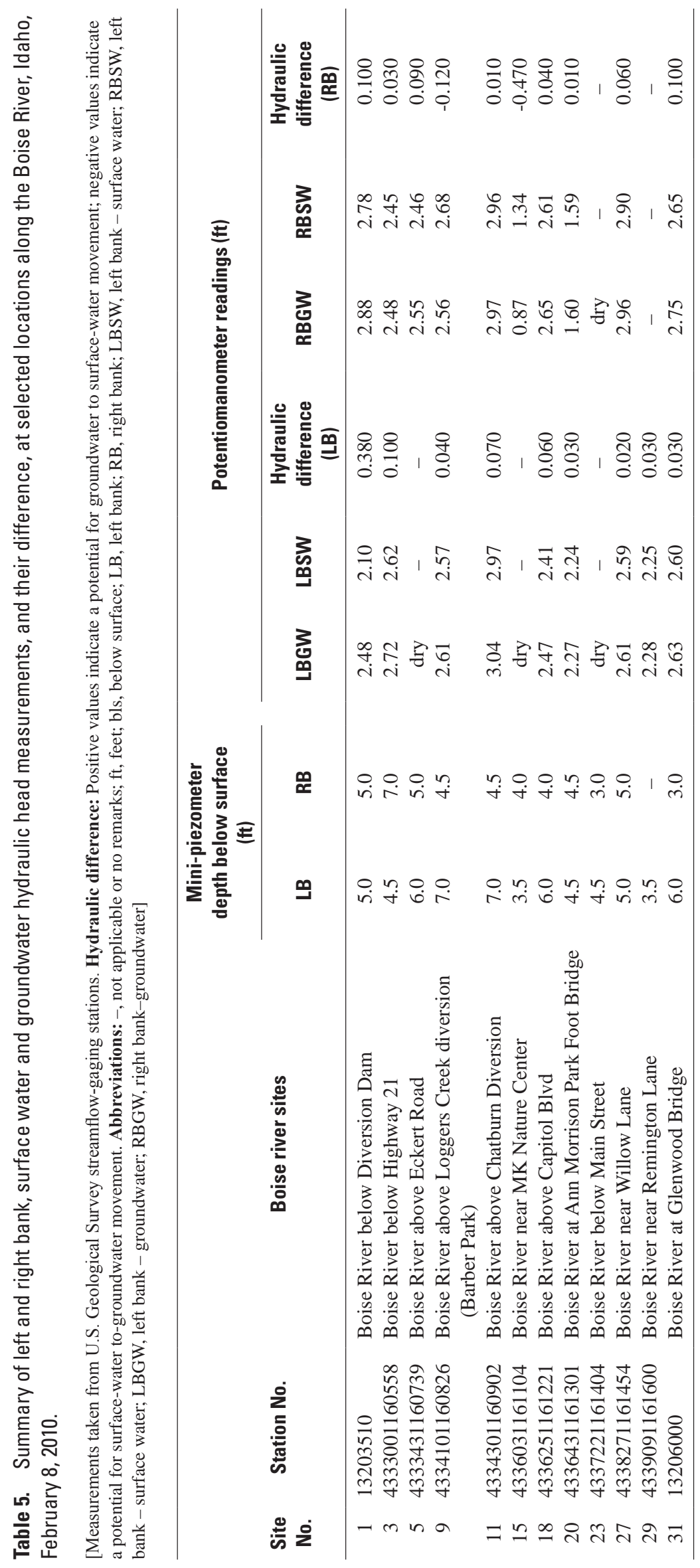



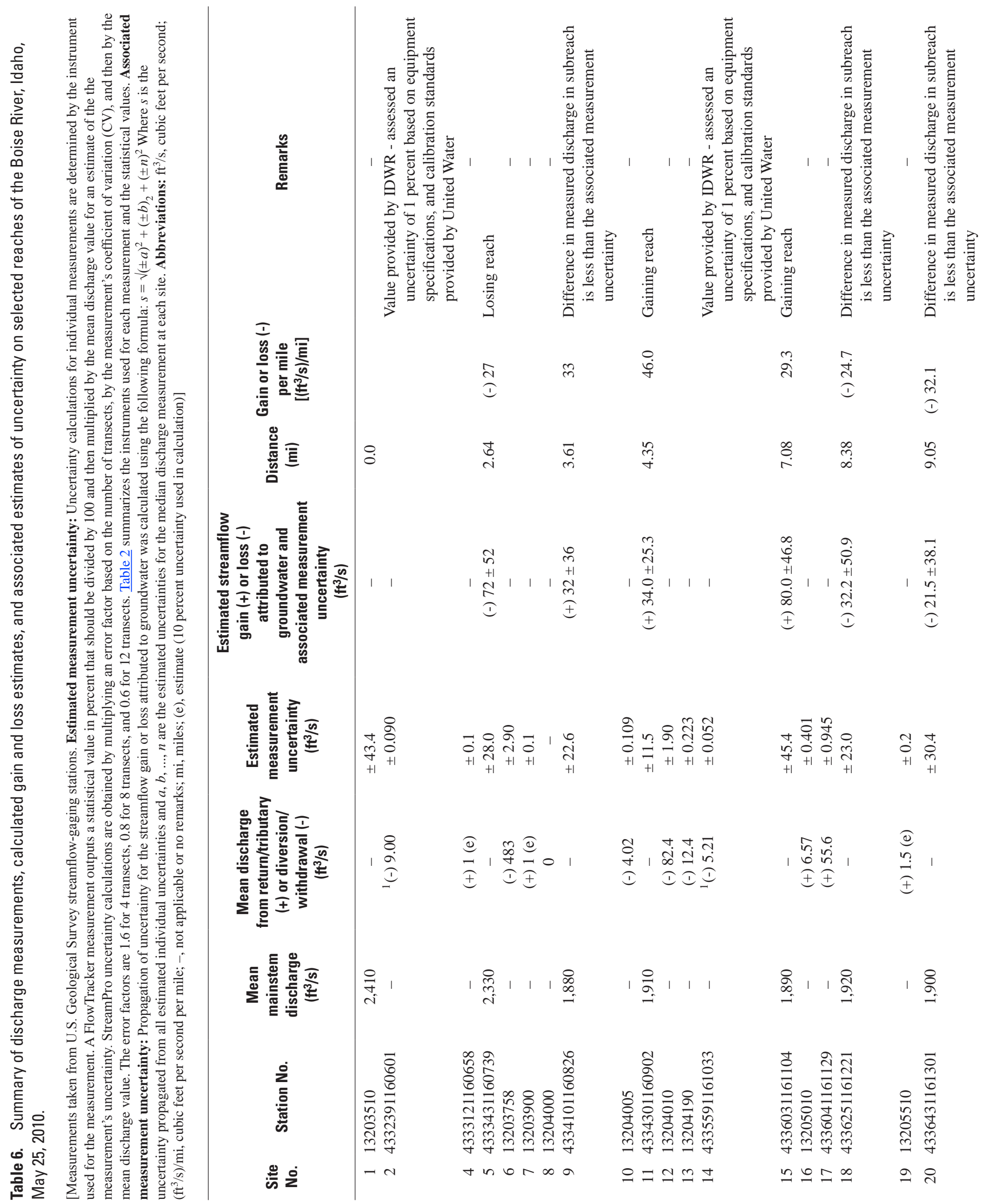


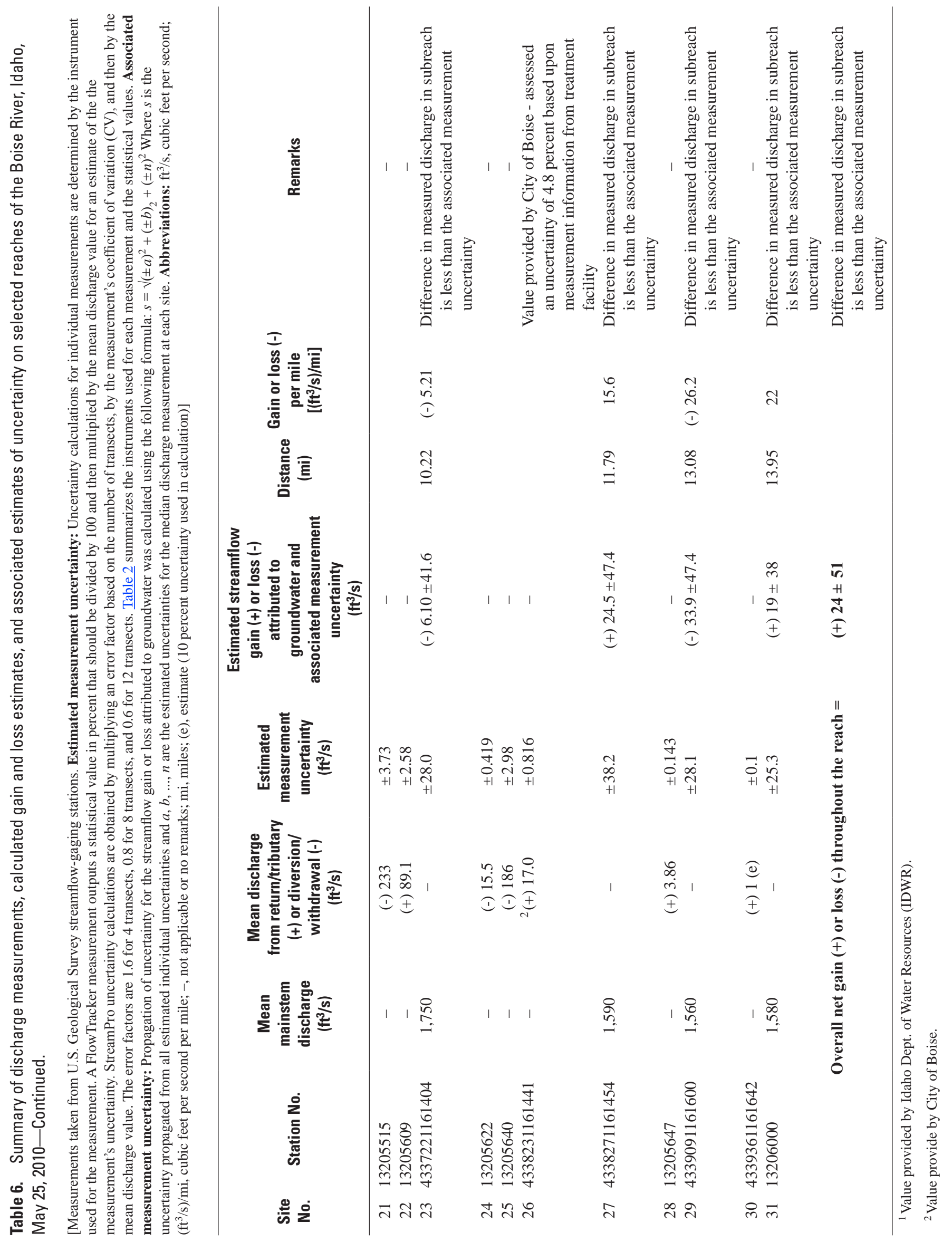


Differential hydraulic head measurements were conducted at mini-piezometers installed along the main reach. In the upper one-half of the reach between sites 1 and 15 , results of the hydraulic head measurements indicated a potential for groundwater to surface-water movement, while the lower one-half of the reach from sites 15 to 31 showed more variability between subreaches (table 7). The right bank at site 15 had the largest negative differential measurement at $-0.53 \mathrm{ft}$, with the right bank at site 23 also showing an indication of groundwater to surface-water movement with a measured differential of $-0.34 \mathrm{ft}$. United Water operates a Ranney collector approximately $0.4 \mathrm{mi}$ upstream of the observation well and was withdrawing $1.71 \mathrm{ft}^{3} / \mathrm{s}$ on the day measurements were taken. Despite this withdrawal, the hydraulic head measurement was similar to the February result when the collector was idle. The potential groundwater to surface-water movement in the upper one-half of the reach is consistent with expectations due to the $1.42 \mathrm{in}$. of rain received within the preceding 5 days and greater permeable surface area than exists in the lower one-half of the reach. If there was an effect by the Ranney collector on groundwater direction near the mini-piezometer at the right bank at site 15, it does not appear to have been significant on May 25, 2010, and may have been due to the recent rainfall. The variability in groundwater movement between subreaches in the lower onehalf of the reach is consistent with urbanized environments where groundwater recharge due to direct precipitation is reduced because large impermeable surfaces such as roads, roof tops, and paved parking areas, with storm drainage systems can quickly carry away surface runoff (Douglas, 1983).

\section{August Seepage Run Results and Analysis}

Stream discharge measurements were conducted on August 3, 2010, along the Boise River, from downstream of the Boise River Diversion Dam to the Glenwood Bridge, with significant returns, tributaries, diversions, and withdrawals measured along the reach. A discharge of $1,770 \mathrm{ft}^{3} / \mathrm{s}$ was measured at site 1, downstream of the Diversion Dam at approximately 3:30 p.m. MST. Irrigation water flows were ongoing, and the National Weather Service (2008) recorded no measureable precipitation at the Boise Airport within 5 days preceding the measurements.

All subreaches had gains or losses greater than the estimates of uncertainty with the exceptions of subreaches 23-27, 27-29, and 29-31. The greatest net gain was between sites 9 and 11 with $105 \pm 84.4 \mathrm{ft}^{3} / \mathrm{s}$, and the greatest net loss was between sites 1 and 5 with $-157 \pm 62 \mathrm{ft}^{3} / \mathrm{s}$ (table 8). Overall, there was a net loss in the reach of $-88 \pm 69 \mathrm{ft}^{3} / \mathrm{s}$.

In the upper one-half of the reach, subreaches $1-5$ and 5-9 were found to be losing, with subreaches 9-11 and 11-15 found to be gaining. The lower one-half of the reach from sites 15 to 31 showed the same variability between subreaches as was found in May, but the gains and losses were not consistent when the subreaches were compared. 


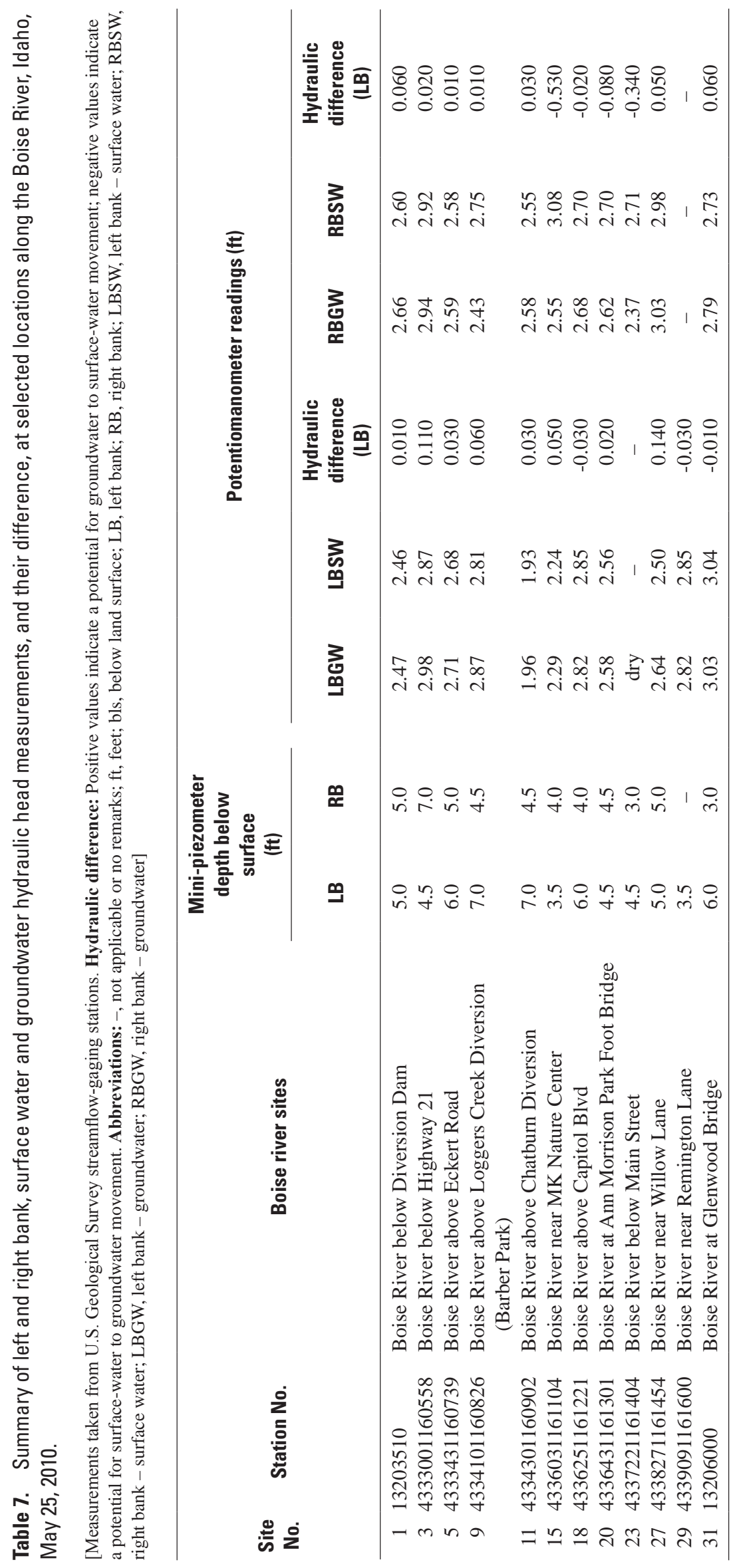




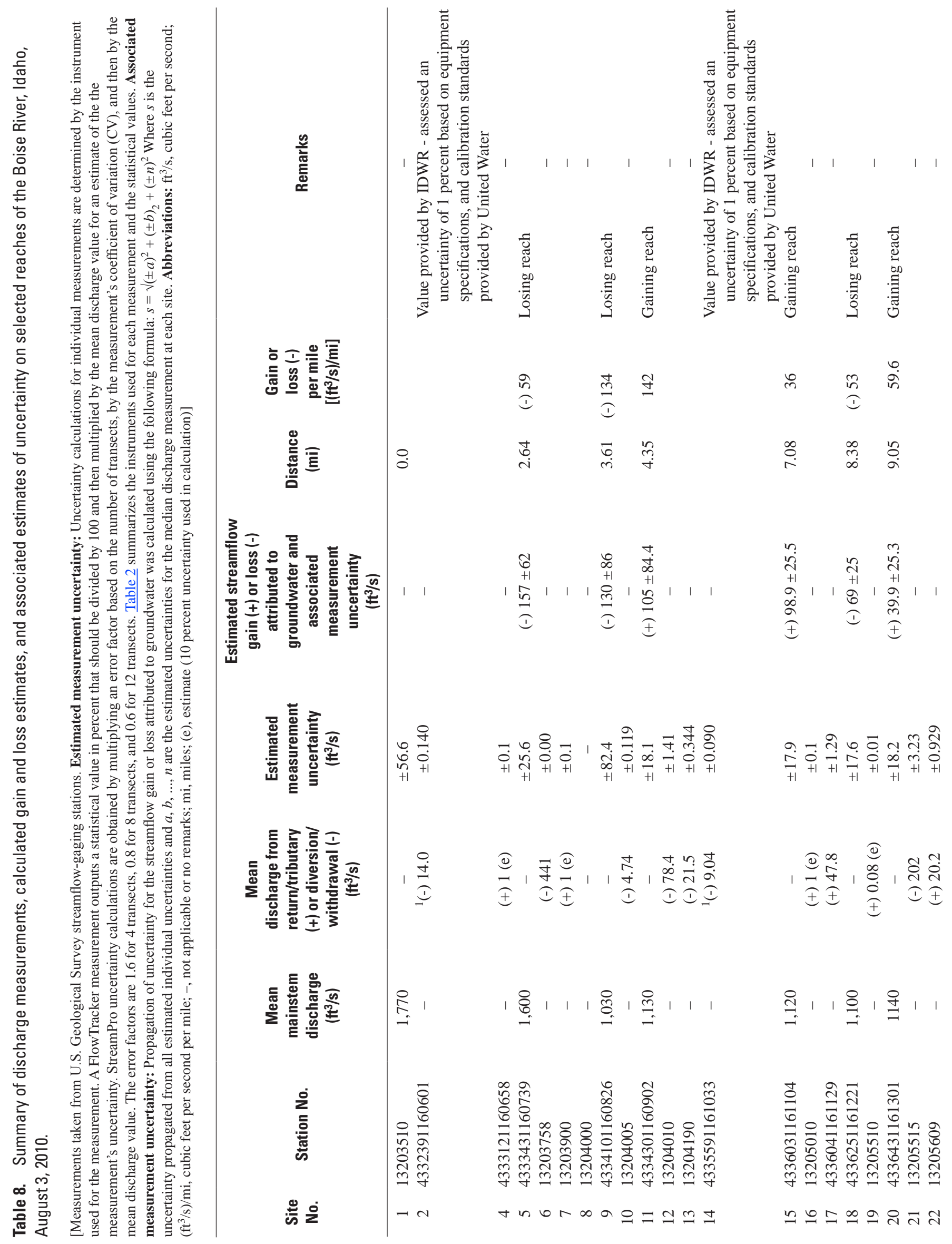




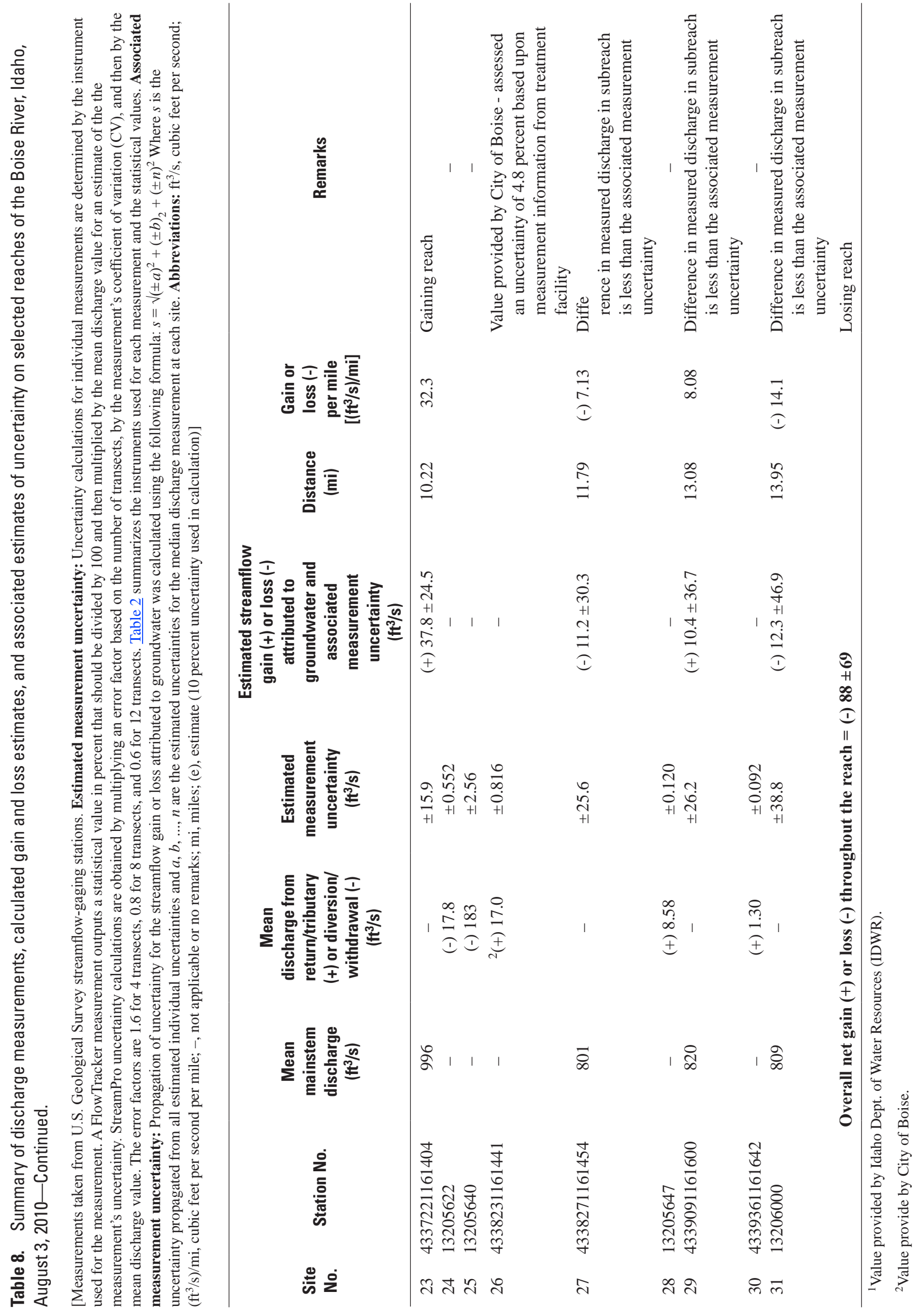




\section{Conclusions}

A four-season comparison, provided by a snapshot of normal conditions in the study reach found the following trends. Groundwater gains and losses in the reach tended to be smaller during fall and winter when there were low stream discharges. During the higher spring and summer stream discharges, the upper end of the reach between sites 1 and 15 had greater magnitude in losses and gains [ -134 to 142 cubic feet per second per mile $\left.\left(\mathrm{ft}^{3} / \mathrm{s} / \mathrm{mi}\right)\right]$ (table 9 ). This is in contrast to the lower one-half of the reach between sites 15 and 31 where the range of variability was only $-53-59.6\left(\mathrm{ft}^{3} / \mathrm{s}\right) / \mathrm{mi}$ (table 9). Subreaches 1-5 consistently gained during low flows, and lost during high flows. Subreaches 9-11 behaved in the opposite manner and always had the greatest gains during high stream discharge regimes and the greatest losses during low stream discharge conditions of any subreach normalized per mile. Subreaches 11-15 gained during all sampling periods, and different stream discharge regimes (fig. 3).

A comparison of groundwater hydraulic potential at low and high stream discharge, on the left and right banks, showed an overall groundwater to surface-water hydraulic trend throughout the reach with the greatest positive hydraulic head differential measured at site 1 , at low stream discharge, of $0.38 \mathrm{ft}$; however, there are some notable exceptions. Site 15 on the right bank, during both high and low stream discharge, had the largest negative hydraulic head differentials of -0.53 and $-0.47 \mathrm{ft}$, respectively, indicating a strong potential for surface-water to groundwater movement at this site. The third largest negative hydraulic head differential occurred on the right bank at site 23 during high flows, with a measured difference of $-0.34 \mathrm{ft}$ (fig. 4).

Table 9. Seasonal summary of mainstem discharge measurements, with calculated gain and loss estimates, and associated estimates of uncertainty, during water year 2010, on selected reaches of the Boise River, Idaho.

[Abbreviations: $\mathrm{ft}^{3} / \mathrm{s}$, cubic feet per second; $\left(\mathrm{ft}^{3} / \mathrm{s}\right) / \mathrm{mi}$, cubic feet per second per mile; -, not applicable or no remarks; mi, miles]

\begin{tabular}{|c|c|c|c|c|c|}
\hline $\begin{array}{l}\text { Site } \\
\text { No. }\end{array}$ & Station No. & $\begin{array}{c}\text { Distance } \\
\text { (mi) }\end{array}$ & $\begin{array}{c}\text { Mean } \\
\text { mainstem } \\
\text { discharge } \\
\left(\mathrm{ft}^{3} / \mathbf{s}\right)\end{array}$ & $\begin{array}{c}\text { Estimated streamflou } \\
\text { gain }(+) \text { or loss }(-) \\
\text { attributed to } \\
\text { groundwater } \\
\text { and associated } \\
\text { measurement } \\
\text { uncertainty } \\
\left(\mathrm{ft}^{3 / s}\right)\end{array}$ & $\begin{array}{c}\text { Gain or loss (-) } \\
\text { per mile } \\
{\left[\left[\left(\mathrm{ft}^{3} / \mathrm{s}\right) / \mathrm{mi}\right]\right.}\end{array}$ \\
\hline \multicolumn{6}{|c|}{ Autumn - November 5, 2009} \\
\hline 1 & 13203510 & 0.0 & 218 & - & - \\
\hline 5 & 4333431160739 & 2.64 & 227 & $(+) 13.1 \pm 7.08$ & 4.96 \\
\hline 9 & 4334101160826 & 3.61 & 228 & $(+) 1.00 \pm 6.32$ & 1.03 \\
\hline 11 & 4334301160902 & 4.35 & 213 & $(-) 15.0 \pm 6.08$ & (-) 20.3 \\
\hline 15 & 4336031161104 & 7.08 & 200 & $(+) 32 \pm 8$ & 12 \\
\hline 18 & 4336251161221 & 8.38 & 221 & $(+) 5 \pm 8$ & 4 \\
\hline 20 & 4336431161301 & 9.05 & 210 & $(-) 11.0 \pm 7.36$ & (-) 16.4 \\
\hline 23 & 4337221161404 & 10.22 & 231 & $(+) 20.0 \pm 5.77$ & 17.1 \\
\hline 27 & 4338271161454 & 11.79 & 230 & $(-) 18.0 \pm 6.09$ & (-) 11.5 \\
\hline 29 & 4339091161600 & 13.08 & 246 & $(+) 16.0 \pm 7.54$ & 12.4 \\
\hline 31 & 13206000 & 13.95 & 245 & (-)1.00 \pm 7.43 & (-) 1.15 \\
\hline \multicolumn{6}{|c|}{ Net gain $(+)$ or loss $(-)$ throughout the reach $=(+) 42 \pm 8$} \\
\hline
\end{tabular}


Table 9. Seasonal summary of mainstem discharge measurements, with calculated gain and loss estimates, and associated estimates of uncertainty, during water year 2010, on selected reaches of the Boise River, IdahoContinued.

[Abbreviations: $\mathrm{ft}^{3} / \mathrm{s}$, cubic feet per second; $\left(\mathrm{ft}^{3} / \mathrm{s}\right) / \mathrm{mi}$, cubic feet per second per mile; -, not applicable or no remarks; mi, miles]

\begin{tabular}{|c|c|c|c|c|c|}
\hline $\begin{array}{l}\text { Site } \\
\text { No. }\end{array}$ & Station No. & $\begin{array}{c}\text { Distance } \\
\text { (mi) }\end{array}$ & $\begin{array}{c}\text { Mean } \\
\text { mainstem } \\
\text { discharge } \\
\left(\mathrm{ft}^{3} / \mathrm{s}\right)\end{array}$ & $\begin{array}{c}\text { stimated streamflon } \\
\text { gain (+) or loss (-) } \\
\text { attributed to } \\
\text { groundwater } \\
\text { and associated } \\
\text { measurement } \\
\text { uncertainty } \\
\left(\mathrm{ft}^{3 / \mathrm{s}}\right)\end{array}$ & $\begin{array}{c}\text { Gain or loss (-) } \\
\text { per mile } \\
{\left[\left(\mathrm{ft}^{3} / \mathrm{s}\right) / \mathrm{mi}\right]}\end{array}$ \\
\hline \multicolumn{6}{|c|}{ Winter - February 8, 2010} \\
\hline 1 & 13203510 & 0.0 & 240 & - & - \\
\hline 5 & 4333431160739 & 2.64 & 242 & $(+) 7.50 \pm 7.20$ & 2.84 \\
\hline 9 & 4334101160826 & 3.61 & 258 & $(+) 16.0 \pm 6.93$ & 16.5 \\
\hline 11 & 4334301160902 & 4.35 & 235 & (-) $23.0 \pm 6.43$ & (-) 31.1 \\
\hline 15 & 4336031161104 & 7.08 & 222 & $(+) 30.2 \pm 8.95$ & 11.1 \\
\hline 18 & 4336251161221 & 8.38 & 245 & $(+) 3 \pm 10$ & 2 \\
\hline 20 & 4336431161301 & 9.05 & 243 & $(-) 2.00 \pm 7.87$ & (-) 2.99 \\
\hline 23 & 4337221161404 & 10.22 & 263 & (+) $19.1 \pm 7.40$ & 16.3 \\
\hline 27 & 4338271161454 & 11.79 & 260 & (- ) $20.0 \pm 7.49$ & $(-) 12.7$ \\
\hline 29 & 4339091161600 & 13.08 & 264 & $(+) 4.00 \pm 11.3$ & 3.10 \\
\hline 31 & 13206000 & 13.95 & 281 & (+) $17.0 \pm 11.1$ & 19.5 \\
\hline \multicolumn{6}{|c|}{ Net gain $(+)$ or loss $(-)$ throughout the reach $=(+) 52 \pm 7$} \\
\hline \multicolumn{6}{|c|}{ Spring - May 25, 2010} \\
\hline 1 & 13203510 & 0.0 & 2,410 & - & - \\
\hline 5 & 4333431160739 & 2.64 & 2,330 & $(-) 72 \pm 52$ & $(-) 27$ \\
\hline 9 & 4334101160826 & 3.61 & 1,880 & $(+) 32 \pm 36$ & 33 \\
\hline 11 & 4334301160902 & 4.35 & 1,910 & $(+) 34.0 \pm 25.3$ & 46.0 \\
\hline 15 & 4336031161104 & 7.08 & 1,890 & $(+) 80.0 \pm 46.8$ & 29.3 \\
\hline 18 & 4336251161221 & 8.38 & 1,920 & (-) $32.2 \pm 50.9$ & (-) 24.7 \\
\hline 20 & 4336431161301 & 9.05 & 1,900 & (-) $21.5 \pm 38.1$ & (-) 32.1 \\
\hline 23 & 4337221161404 & 10.22 & 1,750 & (-) $6.10 \pm 41.6$ & (-) 5.21 \\
\hline 27 & 4338271161454 & 11.79 & 1,590 & (+) $24.5 \pm 47.4$ & 15.6 \\
\hline 29 & 4339091161600 & 13.08 & 1,560 & (-) $33.9 \pm 47.4$ & (-) 26.2 \\
\hline 31 & 13206000 & 13.95 & 1,580 & (+) $19 \pm 38$ & 22 \\
\hline \multicolumn{6}{|c|}{ Net gain $(+)$ or loss $(-)$ throughout the reach $=(+) 24 \pm 51$} \\
\hline \multicolumn{6}{|c|}{ Summer - August 3, 2010} \\
\hline 1 & 13203510 & 0.0 & 1,770 & - & - \\
\hline 5 & 4333431160739 & 2.64 & 1,600 & (-) $157 \pm 62$ & (-) 59 \\
\hline 9 & 4334101160826 & 3.61 & 1,030 & $(-) 130 \pm 86$ & (-) 134 \\
\hline 11 & 4334301160902 & 4.35 & 1,130 & (+) $105 \pm 84.4$ & 142 \\
\hline 15 & 4336031161104 & 7.08 & 1,120 & (+) $98.9 \pm 25.5$ & 36 \\
\hline 18 & 4336251161221 & 8.38 & 1,100 & (-) $69 \pm 25$ & (-) 53 \\
\hline 20 & 4336431161301 & 9.05 & 1,140 & (+) $39.9 \pm 25.3$ & 59.6 \\
\hline 23 & 4337221161404 & 10.22 & 996 & (+) $37.8 \pm 24.5$ & 32.3 \\
\hline 27 & 4338271161454 & 11.79 & 801 & (-) $11.2 \pm 30.3$ & $(-) 7.13$ \\
\hline 29 & 4339091161600 & 13.08 & 820 & (+) $10.4 \pm 36.7$ & 8.08 \\
\hline 31 & 13206000 & 13.95 & 809 & $(-) 12.3 \pm 46.9$ & $(-) 14.1$ \\
\hline \multicolumn{6}{|c|}{ Net gain $(+)$ or loss $(-)$ throughout the reach $=(-) 88 \pm 69$} \\
\hline
\end{tabular}




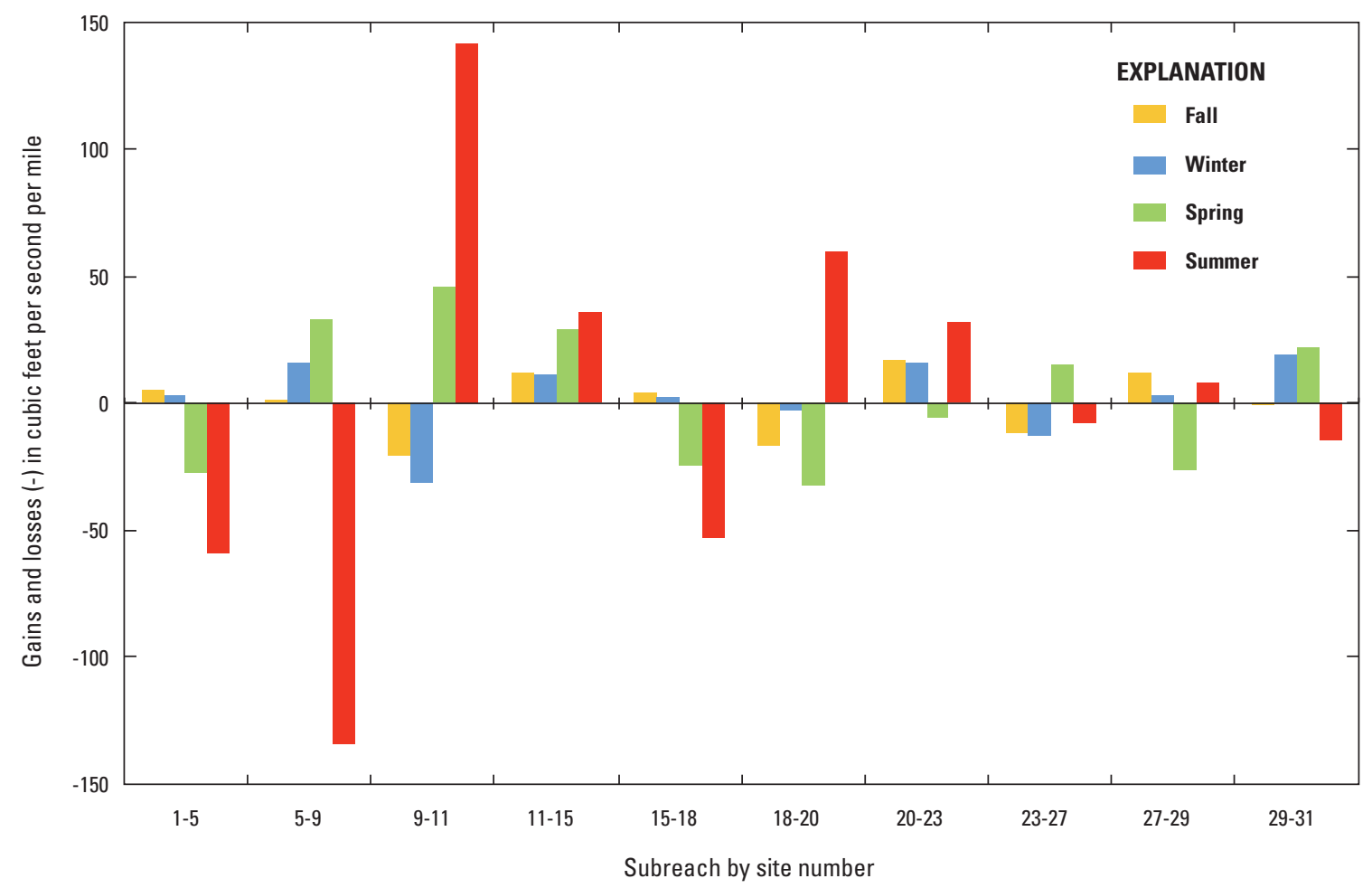

Figure 3. Cumulative seasonal representative gains and losses along subreaches of the Boise River from below the Diversion Dam to the Glenwood Bridge, Boise, Idaho (see figure 1 and table 1 for subreach locations and descriptions).

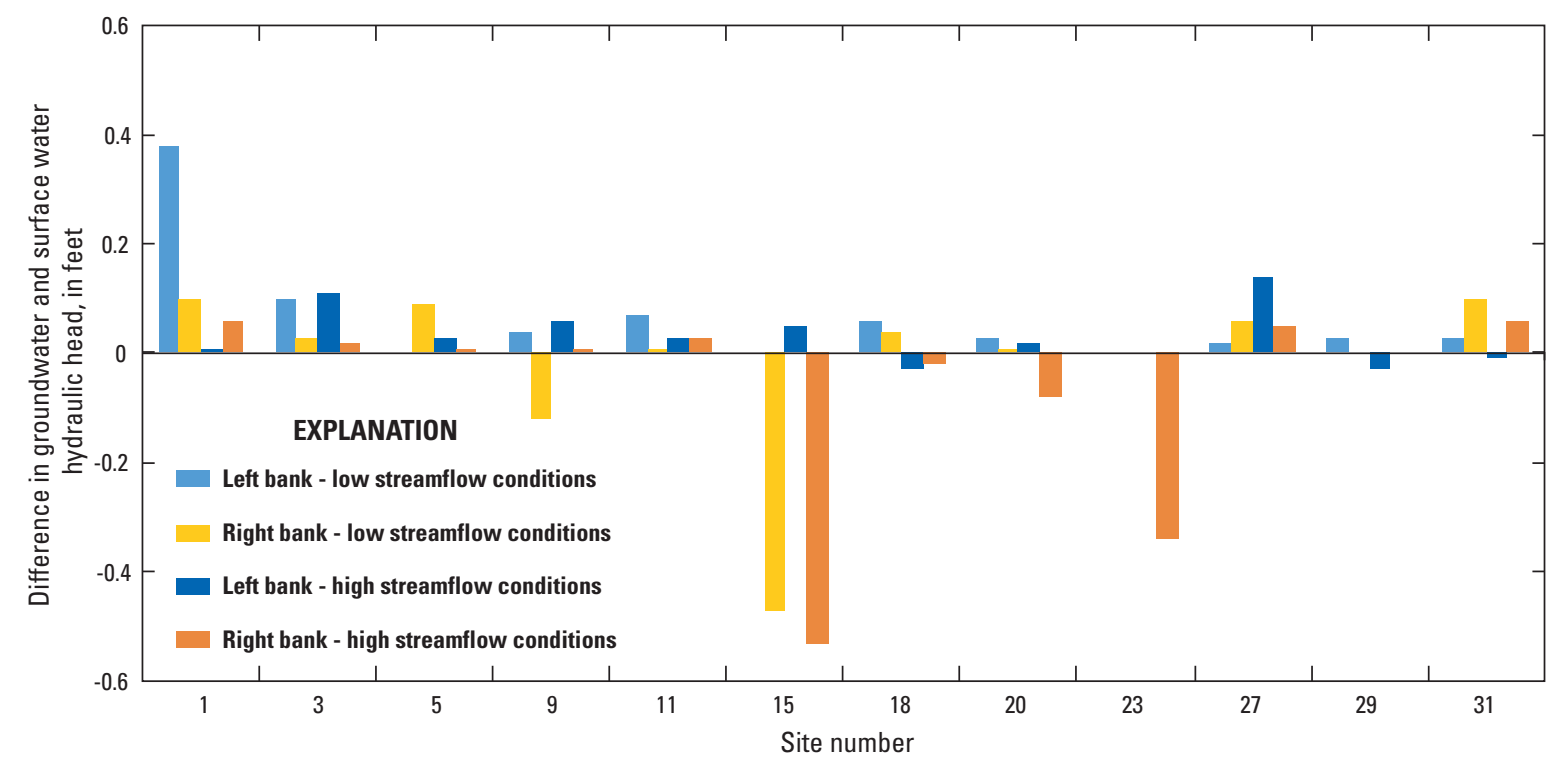

Figure 4. Representative seasonal summary of the difference in hydraulic head measured at transect sites along the Boise River, Idaho (see figure 1 and table 1 for transect locations and descriptions). 


\section{Summary}

The U.S. Geological Survey in cooperation with the Idaho Department of Water Resources Treasure Valley Comprehensive Aquifer Management Planning effort investigated seasonal groundwater gains and losses on the Boise River, Idaho, starting in November 2009 through August 2010. The investigation was conducted using seepage runs in 11 subreaches over a 14-mile reach from downstream of the inactive streamgage, Boise River below Diversion Dam (U.S. Geological Survey station No. 13203510) to the active Boise River at Glenwood Bridge streamgage (U.S. Geological Survey station No. 13206000). The seepage runs measured mainstem discharge, and significant tributary contributions and diversions along the reach. In addition, an evaluation of the groundwater hydraulic gradient was simultaneously conducted through shallow groundwater mini-piezometers adjacent to the river during February (low stream discharge) and May (high stream discharge) measurement timeframes.

November discharge estimates, representative of autumn, had gains and losses that varied by subreach with an overall net gain of $42 \pm 8$ cubic feet per second $\left(\mathrm{ft}^{3} / \mathrm{s}\right)$. This finding compares favorably to a previous U.S. Geological Survey seepage investigation in November 1996 that found a gaining reach with an estimated gain of $52 \mathrm{ft}^{3} / \mathrm{s}$. This finding also is supported by a U.S. Geological Survey investigation in the study reach in November 1971 that estimated a gain of $74 \mathrm{ft}^{3} / \mathrm{s}$, which largely came from groundwater. The February discharge estimates, representative of winter conditions, showed variability in the reach with a net gain of $52 \mathrm{ft}^{3} / \mathrm{s}$ with an uncertainty estimate of $\pm 7 \mathrm{ft}^{3} / \mathrm{s}$, which is consistent with the low stream discharge findings from November 2009. This finding is further supported by the differential hydraulic head measured at transect sites that qualitatively indicated groundwater to surface-water movement with few exceptions. The May discharge estimates, representative of the spring-time conditions, were gaining or potentially gaining in all but one of the upper subreaches between Boise River below Diversion Dam and Boise River near MK Nature
Center sites, with seepage run results supported by hydraulic head differentials indicating a groundwater to surface-water movement. The lower end of the study reach between Boise River near MK Nature Center and Boise River at Glenwood Bridge sites showed more variability with observed hydraulic head differentials that partially supported the potential gains or losses in the reach. Overall, the reach had a calculated net gain of $24 \pm 51 \mathrm{ft}^{3} / \mathrm{s}$; because the net gain does not exceed the estimate of uncertainty, this estimate may or may not reflect the actual conditions in the reach. The groundwater gains and losses in August, representative of summer conditions, varied in both the upper and lower parts of the reach, with a net loss of $-88 \pm 69 \mathrm{ft}^{3} / \mathrm{s}$.

Overall, the reach experienced a net gain from groundwater at low stream discharges (November and February), a net loss to groundwater at moderately high stream discharge (August), and an ambiguous finding at a higher stream discharge (May). The hydraulic head differentials measured between the groundwater and surface water largely supported the calculated gain and loss estimates in the subreaches, with a potential for groundwater to surface -water movement at low stream discharge in February, and variability during high stream discharge conditions in May.

\section{Acknowledgments}

I would like to thank the Idaho Department of Water Resources and United Water for their support and cooperation for the duration of this study, and the USGS Boise Field Office and Idaho Water Science Center personnel who spent long hours in the field conducting all measurements on single sampling days. Their dedication and support was essential in providing dependable data for this investigation. I would also like to thank Molly Wood, the Idaho Water Science Center's Surface Water Specialist for her encouragement and support during this investigation, and Rhonda Weakland, for her assistance on the study area map. 


\section{References Cited}

Berenbrock, C., 1999, Streamflow gains and losses in the lower Boise River basin, Idaho, 1996-97: U.S. Geological Survey Water-Resources Investigations Report 99-4105, $25 \mathrm{p}$.

Douglas, I., 1983, The urban environment: Edward Arnold, $240 \mathrm{p}$.

Mueller, D.S., and Wagner, C.R., 2009, Measuring discharge with acoustic Doppler current profilers from a moving boat: U.S. Geological Survey Techniques and Methods 3A-22, 72 p. (available online at http://pubs.water.usgs.gov/ tm3a22).

National Weather Service, 2008, Observed Weather ReportsPreliminary Monthly Climate Data (CF6)—Boise, Idaho: NOAA National Weather Service Forecast Office database, accessed May 20, 2011 at http://www.weather.gov/climate/ index.php?wfo=boi.

Oberg, K.A., Morlock, S.E., and Caldwell, W.C., 2005, Quality-assurance plan for discharge measurements using acoustic Doppler current profilers: U.S. Geological Survey Scientific Investigations Report 2005-5183, 35 p.

Rantz, S.E., and others., 1982, Measurement and computation of streamflow-volume 1, measurement of stage and discharge: U.S. Geological Survey Water Supply Paper 2175, $284 \mathrm{p}$.
Rosenberry, D.O., and LaBaugh, J.W., 2008, Field techniques for estimating water fluxes between surface water and ground water: U.S. Geological Survey Techniques and Methods 4-D2, 135 p. (available online at http://pubs.usgs. gov/tm/04d02)

Simonds, F.W., and Sinclair, K.A., 2002, Surface water ground water interactions along the Lower Dungeness River and vertical hydraulic conductivity of streambed sediments, Clallam County, Washington, September 1999-July 2001:

U.S. Geological Survey Water Resources Investigation Report 02-4161, 69 p.

SonTek/YSI, 2009, FlowTracker handheld ADV technical manual, firmware version 3.7, software version 2.30: SonTek/YSI, San Diego, CA, 116 p.

Thomas, C.A., and Dion, N.P., 1974, Characteristics of streamflow and ground-water conditions in the Boise River valley, Idaho: U.S. Geological Survey Water-Resources Investigations Report 74-38, 56 p.

Wheeler, J.D., and Eddy-Miller, C.A., 2005, Seepage investigation on selected reaches of Fish Creek, Teton County, Wyoming, 2004: U.S. Geological Survey Scientific Investigations Report 2005-5133, 22 p.

Winter, T.C., LaBaugh, J.W., and Rosenberry, D.O., 1988, The design and use of a hydraulic potentiomanometer for direct measurement of differences in hydraulic head between groundwater and surface water: Limnology and Oceanography, v. 33, no. 5, p. 1209-1214. 
Publishing support provided by the U.S. Geological Survey

Publishing Network, Tacoma Publishing Service Center

For more information concerning the research in this report, contact the Director, Idaho Water Science Center

U.S. Geological Survey

230 Collins Road

Boise, Idaho 83702

http://id.water.usgs.gov

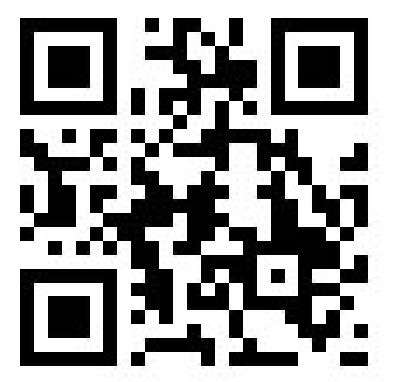




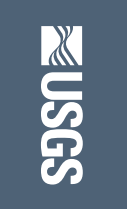

产

ชั้

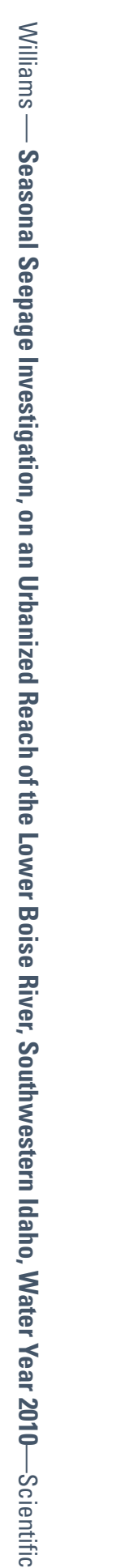

